University of Windsor

Scholarship at UWindsor

2006

\title{
Biological Invasions: Recommendations for U.S. Policy and Management
}

\author{
David M. Lodge \\ University of Windsor \\ Susan Williams \\ University of Windsor \\ Hugh J. Maclsaac \\ University of Windsor \\ Keith R. Hayes \\ University of Windsor \\ Brian Leung \\ University of Windsor
}

See next page for additional authors

Follow this and additional works at: https://scholar.uwindsor.ca/biologypub

Part of the Biology Commons

\section{Recommended Citation}

Lodge, David M.; Williams, Susan; Maclsaac, Hugh J.; Hayes, Keith R.; Leung, Brian; Reichard, Sarah; Mack, Richard N.; Moyle, Peter B.; Smith, Maggie; Andow, David A.; Carlton, James T.; and McMichael, Anthony, "Biological Invasions: Recommendations for U.S. Policy and Management" (2006). Ecological Applications, 16, 6, 2035-2054.

https://scholar.uwindsor.ca/biologypub/1047

This Article is brought to you for free and open access by the Department of Biological Sciences at Scholarship at UWindsor. It has been accepted for inclusion in Biological Sciences Publications by an authorized administrator of Scholarship at UWindsor. For more information, please contact scholarship@uwindsor.ca. 


\section{Authors}

David M. Lodge, Susan Williams, Hugh J. Maclsaac, Keith R. Hayes, Brian Leung, Sarah Reichard, Richard N. Mack, Peter B. Moyle, Maggie Smith, David A. Andow, James T. Carlton, and Anthony McMichael 


\title{
ESA Report
}

\section{BIOLOGICAL INVASIONS: RECOMMENDATIONS FOR U.S. POLICY AND MANAGEMENT}

\author{
David M. Lodge, ${ }^{1,13}$ Susan Williams, ${ }^{2}$ Hugh J. Macisaac, ${ }^{3}$ Keith R. Hayes,${ }^{4}$ Brian Leung, ${ }^{5}$ Sarah Reichard, ${ }^{6}$ \\ Richard N. Mack, ${ }^{7}$ Peter B. Moyle, ${ }^{8}$ Maggie Smith, ${ }^{9}$ David A. Andow, ${ }^{10}$ James T. Carlton, ${ }^{11}$ \\ And Anthony McMichael ${ }^{12}$ \\ ${ }^{1}$ Department of Biological Sciences, P.O. Box 369, University of Notre Dame, Notre Dame, Indiana 46556 USA \\ ${ }^{2}$ Bodega Marine Laboratory, University of California-Davis, Bodega Bay, California 94923-0247 USA \\ ${ }^{3}$ Great Lakes Institute for Environmental Research, University of Windsor, Windsor, Ontario N9B 3P4 Canada \\ ${ }^{4}$ CSIRO Marine and Atmospheric Research, GPO Box 1538, Hobart, Tasmania 7001 Australia \\ ${ }^{5}$ Department of Biological Sciences, P.O. Box 369, University of Notre Dame, Notre Dame, Indiana 46556 USA \\ ${ }^{6}$ University of Washington, Center for Urban Horticulture, Box 354115, Seattle, Washington 98195 USA \\ ${ }^{7}$ School of Biological Sciences, Washington State University, Pullman, Washington 99164 USA \\ ${ }^{8}$ Department of Wildlife, Fish, and Conservation Biology, University of California, 1 Shield Avenue, Davis, California 95616 USA \\ ${ }^{9}$ The Ecological Society of America, 1707 H Street NW, Suite 400, Washington, D.C. 20009 USA \\ ${ }^{10}$ Department of Entomology, University of Minnesota, 219 Hodson Hall, 1980 Folwell Avenue, Saint Paul, Minnesota 55108 USA \\ ${ }^{11}$ Maritime Studies Program, Williams College-Mystic Seaport, Mystic, Connecticut 06355 USA \\ ${ }^{12}$ National Centre for Epidemiology and Population Health, The Australian National University, Canberra, \\ Australian Capital Territory 0200 Australia
}

Abstract. The Ecological Society of America has evaluated current U.S. national policies and practices on biological invasions in light of current scientific knowledge. Invasions by harmful nonnative species are increasing in number and area affected; the damages to ecosystems, economic activity, and human welfare are accumulating. Without improved strategies based on recent scientific advances and increased investments to counter invasions, harm from invasive species is likely to accelerate. Federal leadership, with the cooperation of state and local governments, is required to increase the effectiveness of prevention of invasions, detect and respond quickly to new potentially harmful invasions, control and slow the spread of existing invasions, and provide a national center to ensure that these efforts are coordinated and cost effective.

Specifically, the Ecological Society of America recommends that the federal government take the following six actions: (1) Use new information and practices to better manage commercial and other pathways to reduce the transport and release of potentially harmful species; (2) Adopt more quantitative procedures for risk analysis and apply them to every species proposed for importation into the country; (3) Use new cost-effective diagnostic technologies to increase active surveillance and sharing of information about invasive species so that responses to new invasions can be more rapid and effective; (4) Create new legal authority and provide emergency funding to support rapid responses to emerging invasions; (5) Provide funding and incentives for cost-effective programs to slow the spread of existing invasive species in order to protect still uninvaded ecosystems, social and industrial infrastructure, and human welfare; and (6) Establish a National Center for Invasive Species Management (under the existing National Invasive Species Council) to coordinate and lead improvements in federal, state, and international policies on invasive species.

Recent scientific and technical advances provide a sound basis for more cost-effective national responses to invasive species. Greater investments in improved technology and management practices would be more than repaid by reduced damages from current and future invasive species. The Ecological Society of America is committed to assist all levels of government and provide scientific advice to improve all aspects of invasive-species management.

Key words: control of invasive species; cost-effective programs; diagnostic technologies; globalization; importation; invasive species; pathways of invasion and spread; rapid response to invasive species; risk assessment; slow-the-spread strategy; surveillance.

Manuscript received 11 April 2006; revised 12 June 2006; accepted 13 June 2006. Corresponding Editor: D. S. Schimel. This article is based on a Position Paper commissioned by the Governing Board of the Ecological Society of America. Reprints of this 20-page report are available for $\$ 3.00$ each, either as a PDF file or as hard copy. Prepayment is required. Order reprints from the Ecological Society of America, Attention: Reprint Department, 1707 H Street, N.W., Suite 400, Washington, DC 20006 USA (e-mail: esaHQ@esa.org).

${ }^{13}$ E-mail: lodge.1@nd.edu 


\section{INTRODUCTION}

Invasions by nonindigenous species are a growing global problem, costing U.S. taxpayers hundreds of billions of dollars annually in environmental degradation, lost agricultural productivity, expensive prevention and eradication efforts, and increased health problems (Vitousek et al. 1996, Mack et al. 2000, Sala et al. 2000, Mooney et al. 2005). The only study to attempt a nationwide estimate of the economic costs to the United States of nonindigenous species concluded that annual costs exceed $\$ 120$ billion (Pimentel et al. 2005) or about $\$ 1100$ per household annually. While Pimentel et al. (2005) did not account for the economic benefits that some of the species provide, they also examined only a small subset of harmful species, and did not include many environmental damages caused by the species that were examined. Including these other factors would likely mean that the net costs of invasive species are much higher, and they are clearly growing.

Zebra mussels alone cost each infested large power plant \$3 million annually (Leung et al. 2002), and are still spreading throughout the waterways of the United States (Drake and Bossenbroek 2004). In two Californian lagoons, more than $\$ 5$ million were spent in the first three years of an on-going eradication program for the seaweed Caulerpa taxifolia. At least $\$ 3$ million annually are spent in Florida to control the Australian melaleuca tree (Melaleuca quinquenervia; Pimentel et al. 2005). These and many other expenditures occur because the damages that result from inaction are more costly. Without management, the populations of these species grow and spread so that damages accelerate over time. In contrast to many other forms of pollution, such widespread invasions become irreversible because often the technology does not exist to selectively eradicate species. Relative to the economic and ecological costs of other forms of environmental pollution, the costs of nonindigenous species are therefore of particular concern because they are likely to be borne over very long time frames.

Many long-term changes in ecosystems and the goods and services that they provide to humans are driven by nonindigenous species, including, for example, degradation of U.S. western rangeland and increased fire damage caused by the widespread invasion by Bromus tectorum (cheatgrass; Grace et al. 2001). Some nonindigenous species were introduced intentionally and continue to be highly valued by humans, e.g., agriculture and aquaculture species. Many other species, e.g., West Nile virus, were introduced as by-products of human travel and international commerce, have no utility for humans, and have strong net negative impacts on the environment, industry, and human health.

We highlight in this report the policy and management recommendations that follow logically from recent scientific and technical advances in our understanding of biological invasions (Table 1). These recommendations are especially timely because U.S. state and federal agencies are developing new approaches to reduce the negative environmental, economic, and human-health impacts of nonindigenous species. The National Invasive Species Council (NISC), advised by the Invasive Species Advisory Committee (ISAC), published the first edition of a National Management Plan (NMP) for invasive species in January 2001 (available online). ${ }^{14}$ Our recommendations are consistent with the NMP, but we emphasize some priorities among its many recommendations. The science of ecology and the expertise within the Ecological Society of America, in particular, can offer much guidance in the implementation of the NMP's goals at state, federal, and international levels. In this paper we focus on recommendations that require U.S. federal leadership to better coordinate international, federal, state, and local governmental responses.

\section{Definitions}

A potentially confusing set of terms has developed around biological invasions. In this report, nonindigenous means a species that by human influence occurs outside its native range. Synonyms include "nonnative," "alien," and "exotic"; alien is the term used in the NMP and in many discussions involving U.S. federal agencies (see footnote 14). Species that spread widely beyond the location of initial establishment, become locally abundant, or spread into natural areas, are referred to as invasive. Clearly, then, the definition of "invasive" depends on time and spatial scale, which must therefore be specified.

In many policy and legal documents in the United States and other countries, another component is added to the definition of invasive: the species causes or is likely to cause net harm to the economy, environment, or human health. The definition of "harm" is a function of human values, which often differ in different regions, and may change temporally. Overall then, scientists can-with specified temporal and spatial scales-define nonindigenous status and spread, and can describe the loss of native species and other ecological changes caused by nonindigenous species. However, deciding whether such ecological changes or impacts on industry or human health constitute net harm requires additional input through a broader democratic process that includes economists, public-health experts, and ecologists (National Research Council 1996, Hayes and Sliwa 2002, Lodge and Shrader-Frechette 2003, Andow 2004, Drake and Keller 2004).

While some species native to a given region are invasive (Van Auken 2000), these species are not the focus of current policy discussions, and not the topic of this report. Thus, we focus in this report on the subset of

\footnotetext{
14 〈www.invasivespeciesinfo.gov〉
} 
TABLE 1. Summary of major recommendations, recent scientific and technical advances that make possible the implementation of the recommendations, and the organization(s) proposed to lead the implementation of each recommendation.

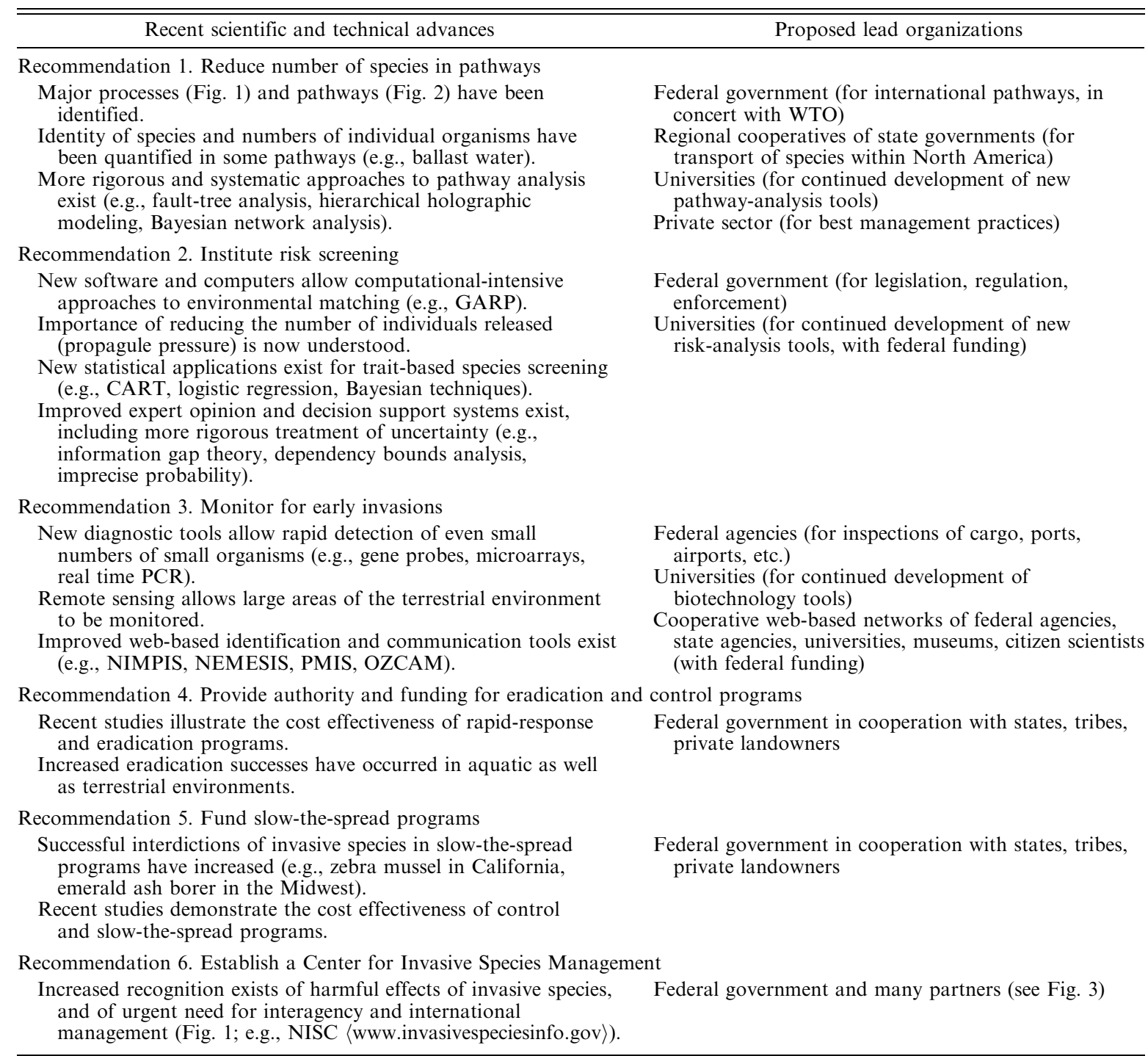

Notes: CART, classification and regression trees; GARP, genetic algorithm for rule-set production; NEMESIS, National Exotic Marine and Estuarine Species Information System; NIMPIS, National Introduced Marine Pest Information System; NISC, the National Invasive Species Council; OZCAM, Online Zoological Collections of Australian Museums; PCR, polymerase chain reaction; PMIS, Plant Management Information System; WTO, the World Trade Organization.

nonindigenous species that are invasive; that is, we focus on invasive nonindigenous species, which we will hereafter abbreviate as invasive species. Additional discussions of terminology and related issues are available in Davis and Thompson (2000), Richardson et al. (2000), Lodge and Shrader-Frechette (2003), Colautti and MacIsaac (2004), Donlan and Martin (2004), and Pysek et al. (2004).

\section{Process of invasion}

At one level, the issue of invasive species is well illustrated by thousands of different examples, replete with idiosyncratic biological details, from brown tree snakes on Guam to snakehead fish in Maryland to monkey pox in the Midwest. At another more basic level, such catalogs of examples obscure the biological processes that are common to all invasions, and that hold the key to scientific analysis and appropriate policy and management responses (Fig. 1). Species are carried in a pathway, the purpose of which may be to transport species (e.g., the pet and horticultural trades) or in which the transport of species is incidental to the primary human purpose (e.g., insect pests in lumber shipments, many different kinds of organisms in ballast water of 

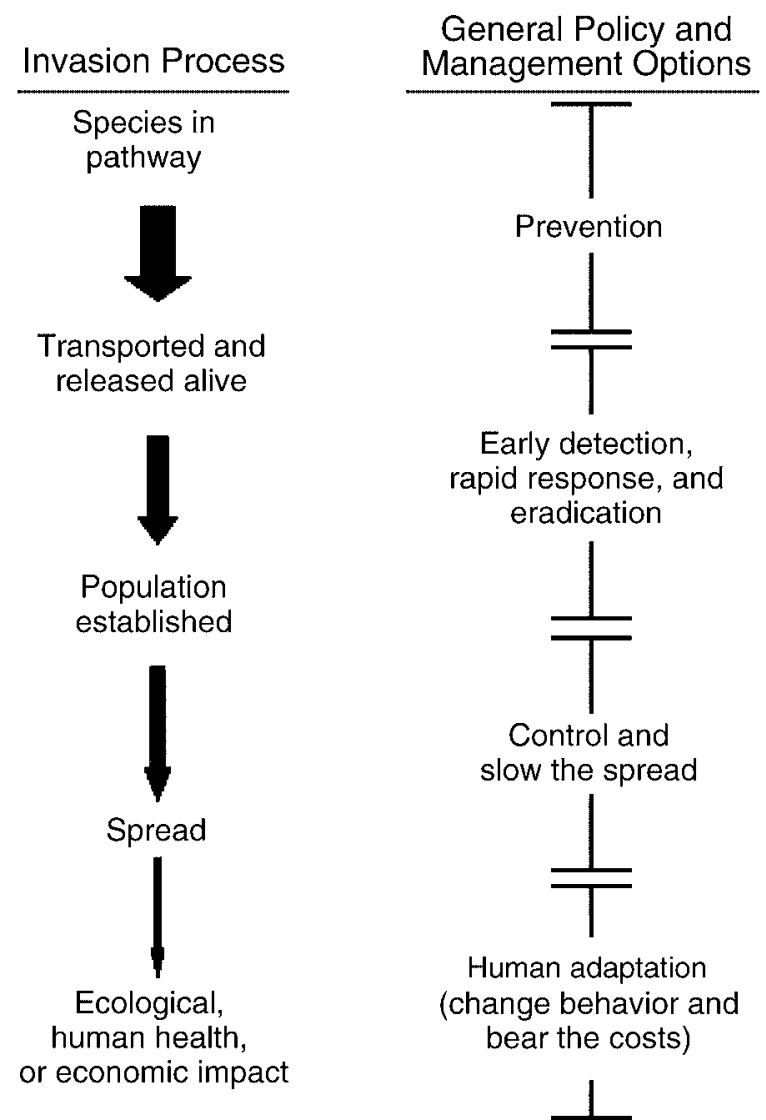

\section{Specific Recommendations}

1) Reduce species in pathways

2) Institute risk screening

3) Monitor for early invasions

4) Provide authority and funding for eradication and control programs

5) Fund slow-the-spread
programs

6) Establish National Center for Invasive Species Management

FIG. 1. Stages common to all invasions by nonindigenous species (left column), major policy and management options (middle column), and major recommendations (right column) associated with each stage of invasion. From the top to the bottom of the left column, each arrow is thinner than the preceding one because the proportion of species that proceeds from one step to the next is less than the previous one. Nevertheless, because the number of species entering pathways is increasing as global trade increases, the number of species causing harmful impacts is increasing with time. In the right column, recommendations do not correspond exactly with each stage of invasion; in particular, recommendation 6 underpins all policy and management options.

ships, viruses carried by humans themselves). Depending on the conditions and the duration in the pathway, some proportion of the organisms will be alive when they are released or escape at a location outside the geographic area where they previously occurred.

Many such nonindigenous species subsequently go extinct in a new location, but a proportion, about $50 \%$ for animal species (Jeschke and Strayer 2005), establishes a self-sustaining population (Mack et al. 2000). At the next stage of invasion, many established species remain localized, and most are probably not even detected by humans. Yet a proportion of established species, about $50 \%$ for animals (Jeschke and Strayer 2005), spread widely and become abundant at many new locations, sometimes after a lag phase of many years in which populations remained small and localized (O'Dowd et al. 2003). Such species are then classified as invasive, and because of their abundance, they cause detectable ecological changes, which are often viewed as harmful. Human health is sometimes affected, and economic costs are often incurred (Pimentel et al. 2005).

Policy and management implications become clear when these common processes and probabilistic transitions during invasion are recognized. The possible human management responses narrow as any invasion progresses (Fig. 1). Prevention is possible only early in the process, before a species arrives in a new range or at the point of entry. Once a species is well established, eradication is costly and sometimes impossible. Eradication therefore depends on the rapid convergence of appropriate technology, political will, and resources.

In the United States, most eradication attempts occur when direct risks to human health loom. The arrival via international travel and trade of viral pathogens of many organisms, including humans (e.g., West Nile virus, monkey pox, SARS, and HIV) (Breiman et al. 2003, CDC 2003, Chan-Yeung and Yu 2003, Check 2004, Lingappa et al. 2004) and parasite vectors (e.g., Asian tiger mosquito, Aedes albopictus, that can carry 
dengue and yellow fever; Reiter and Sprenger 1987, Moore 1999, Linthicum et al. 2003) have all prompted substantial management and policy responses in the United States. Nevertheless, only monkey pox and SARS have been eradicated, while West Nile virus, Asian tiger mosquito, and HIV are now widespread. We are not addressing human diseases in this paper, but we do consider management and policy responses to diseases as an instructive example for responses to other invasive species. The activities of the U.S. Centers for Disease Control and Prevention (CDC) are especially relevant. The processes of emergence of human diseases are often the same as those for other invasive species, including wildlife diseases, which we evaluate here. Indeed, many parasites, including West Nile virus and monkeypox, affect both humans and many other domestic animals and wildlife species. The management and policy responses to disease therefore offer a touchstone for evaluating current societal responses to other invasive species. For both human parasites and other invasive species, once the opportunity for eradication has passed, few options remain: control of populations in selected locations, slowing the spread of species, and adaptation by humans.

Even when the technology and political will for control efforts exists, resources must be made available in perpetuity, unlike many other types of pollution abatement. For example, expenditures in response to West Nile virus in Louisiana alone for just nine months in 2002-2003 were \$20 million (Zohrabian et al. 2004). For non-health related species, the costs of control are typically lower, but still substantial. The United States and Canada have spent at least $\$ 16$ million annually since 1956 to reduce sea lamprey populations to a level at which losses to the Great Lakes fisheries are acceptable, and Florida spends \$14 million annually for control of nonindigenous aquatic plants (Schmitz et al. 1993). While these and other control programs are successful, similar efforts are too rarely attempted. Instead, the default response in U.S. policy is adaptation-passively adjusting to the damages caused by new species - even when, as is often the case, eradication or control would be a more cost-effective response.

Overall, only a fraction of introduced nonindigenous species establishes, and only a small proportion of those species pose a direct threat to human health or are otherwise invasive (Williamson 1996; Fig. 1). Nevertheless, the number of invasive species in the United States and elsewhere is large and continuing to grow because of increasing global movements of humans and goods. For example, the numbers of nonindigenous plant pathogens, insects, and mollusks discovered in the United States since 1920 are strongly correlated with importation of goods over the same time period, and are forecast to increase by $16-24 \%$ over the next 20 years (Levine and D'Antonio 2003). As the world's largest economy and home to many of the world's richest ecosystems, the United States is particularly vulnerable to additional biological invasions. We therefore emphasize the urgent need for more effective efforts of prevention, eradication of newly established nonindigenous species, and control of currently invasive species. We assess general policy approaches in light of recent scientific advances (Table 1), and make six recommendations requiring policy and management action.

\section{Prevention}

Policy makers should focus on early steps in the invasion process because that is where the most costeffective responses are possible (Fig. 1): preventing organisms from entering a pathway, and preventing organisms that are transported from being released or escaping alive. Thus, prevention efforts must include a focus on pathways (Ruiz and Carlton 2004).

Once a highly invasive species arrives, it is difficult to prevent rapid spread. For example, many introduced plant species disperse freely by wind, water, or animals, and via roads and riparian zones, to many new ecosystems. One purple loosestrife plant (Lythrum salicaria) can produce thousands of seeds that are readily transported downstream by water to new locations along river networks, establishing new populations (Malecki et al. 1993, Galatowitsch et al. 1999), while terrestrial species invade roadways and highway edges (Randall and Marinelli 1996). The matrix of roads and riparian zones facilitates subsequent invasions into more remote areas. With more than a hundred species of birds as potential carriers of West Nile virus, the pathogen spread from New York to much of North America in just three years (Campbell el al. 2002). Many insects also disperse long distances each year. Likewise, in freshwater and marine environments, many organisms have pelagic life stages that are rapidly transported long distances. The difficulties and expense of reversing such invasions mean investment in prevention is likely to be the most successful and cost-effective response to biological invasions.

\section{Recommendation 1}

Use a combination of existing and new technologies, education strategies, industry codes of conduct, and government oversight to prevent introductions from pathways that already are well known to be major sources of nonindigenous species, and to monitor other pathways into the United States to better assess the degree of risk they pose.

The U.S. national Invasive Species Advisory Committee (ISAC) has identified the major pathways by which species are intentionally and unintentionally imported into the United States (Fig. 2). This analysis is a necessary first step in a risk analysis of invasion pathways. If policy attention and management resources 


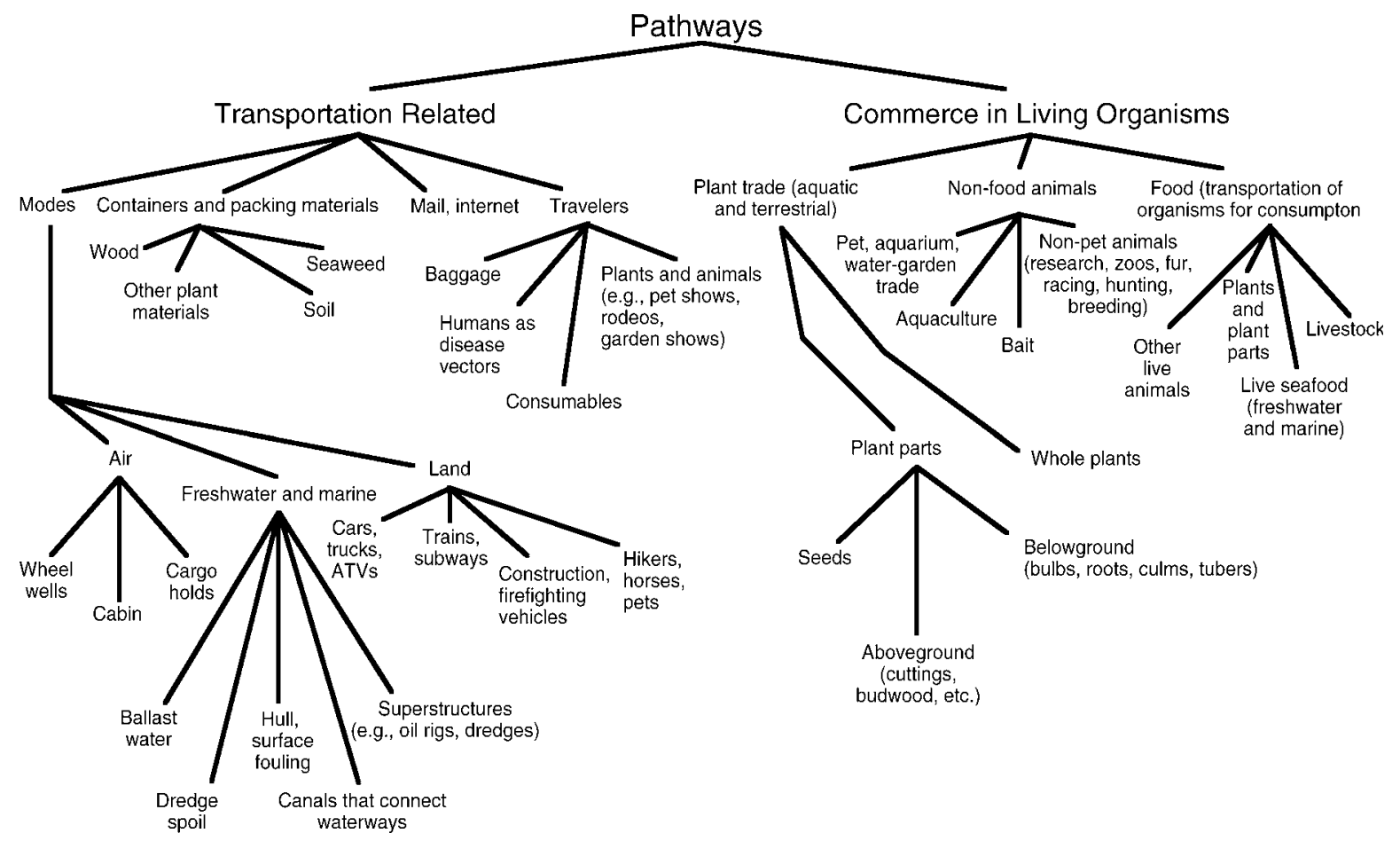

FIG. 2. Major pathways by which nonindigenous species enter the United States and are transported within the United States. For the right-hand branch of pathways (Commerce in Living Organisms), each pathway also entails the possibility of other species hitchhiking on or in the species that is the focus of trade, or in the medium (e.g., water, soil, nesting material) or food of the focal species. Hitchhiking organisms could include parasites and pathogens of the species in trade. The figure is revised and simplified from the 29 October 2003 Final Report by the ISAC Invasive Species Pathways Team of the Prevention Working Group /http:// www.invasivespeciesinfo.gov/council/wrkgrps.shtml $>$.

are to be prioritized and cost-effectively applied across pathways, the relative risk posed to the environment, human health, and the economy by different pathways must also be better quantified. This is increasingly possible using new tools for detection of organisms (e.g., genetic tools; see also Recommendation 3) and quantitative analysis of pathways (e.g, network analyses; Hayes et al. 2004, Burgman 2005).

The invasion risk associated with a pathway is a function of the number of nonindigenous species transported, the number of individuals of each species transported, the characteristics of the species (including their environmental tolerances), the number and characteristics of their hitchhiking species (including parasites, and other associated organisms), and the likelihood and frequency that a species and associated hitchhikers would be released or escape into an environment suitable for the species to thrive (either initially or through secondary transport). Other relevant considerations are the feasibility and cost of eradication or control should a species become invasive. For terrestrial and aquatic ecosystems, we briefly discuss the most important pathways here.

For many transportation-related pathways and pathways of commerce in living organisms (Fig. 2), the information available falls short of that necessary for a complete risk assessment, but is nevertheless sufficient to justify strong immediate policy and management actions. Ship traffic, for example, connects every port in the world (Drake and Lodge 2004), and is responsible for the movement of a large proportion of terrestrial and aquatic nonindigenous species (Carlton et al. 1995). Terrestrial species arrive in containers, packing materials, and personal luggage (Kiritani and Yamamura 2003, Kraus 2003). In San Francisco Bay, hull fouling and ballast contents each contributed about $25 \%$ of all known aquatic introductions (Cohen and Carlton 1998). For Australia, hull fouling contributed $49 \%$ and ballast $21 \%$ (K. Hayes, unpublished data). Other major transportation-related pathways include canals and aqueducts (which connect previously unconnected watersheds) (Stokstad 2003). Large investments in prevention along these transportation-related pathways will be cost effective because management will simultaneously prevent numerous species in the same pathway.

Commerce in living organisms (Fig. 2) usually introduces species at a lower rate than transportationrelated pathways. However, prevention efforts will often still be very cost-effective for these pathways because risk assessment and management are likely to be less 
expensive than for transportation-related pathways. For terrestrial ecosystems, the most damaging intentional pathways have been horticulture, the seed trade, freshfood commerce, and the pet trade (Kraus 2003, Mack 2003). For freshwater ecosystems, stocking (especially of fishes, Rahel 2002), the pet industry (Padilla and Williams 2004), the bait industry (Kolar and Lodge 2001), aquaculture (Cohen and Carlton 1998), and the live-food industry (Benson 1999, Fuller et al. 1999) have been most harmful. The water-garden (Lodge et al. 2000) and live-food (Chapman et al. 2003, Rixon et al. 2004) industries are growing rapidly and are therefore likely to be an increasing source of nonindigenous species. The water-garden, bait, and aquaculture industries are especially troublesome because they often put many nonindigenous species of plants and animals in close proximity to natural waterways and terrestrial ecosystems where the probability of escape and establishment is high (Les and Mehrhoff 1999). In addition to intentionally transported species, these same industries often deliver many species hitchhiking on the focal species (e.g., parasites, other easily overlooked plant, animal, and microbial species; Palm and Rossman 2003). Increasing trade via mail order as a result of purchases on the internet increases the risk from these pathways (Fig. 2).

On the basis of what is already known about these pathways, some specific recommendations emerge:

- Much greater federal effort should be expended to inspect, interdict, and enforce regulations, especially for ship-related pathways (ballast tank contents, hull fouling, and containers). Regulations must be extended to ships that have only residual (but nevertheless organism rich) water and sediment in their ballast tanks (so-called "no-ballast-on-board" or NOBOB ships; Colautti et al. 2003). New technologies for detection of transportation-related terrorist threats should be expanded and applied also to nonindigenous species, including gene probes, microarrays, and remote sensing that would provide more cost-effective monitoring to supplement increased efforts by human inspectors (NRC 2003; see Recommendation 3).

- Current efforts to identify cost-effective alternatives to ballast-water exchange (BWE) should be accelerated and implemented more quickly than required by the International Maritime Organization's 2004 International Convention for the Control and Management of Ships' Ballast Water and Sediments. BWE is not effective against all invasive species and takes too long to implement effectively for many short-distance coastal voyages. Urgently needed are management alternatives that prevent initial infection of the vessel or remove or kill entrained organisms before de-ballasting.

- Federal agency statistics on inspections and the species discovered should be better maintained and made available for analyses of pathways and the effectiveness of alternative prevention strategies. Current data kept by USDA APHIS (Animal, Plant, and Health Inspection service), for example, are insufficient and practically unavailable (NRC 2002). Without such information, the cost-effectiveness of prevention methods will remain unknown and improvements difficult to document. In the rare cases where comprehensive inspections have occurred, the value of prevention was overwhelming. For example, inspections by the Hawaii Department of Agriculture of air cargo at Kahului Airport, Maui, during 20 weeks in 2000-2001, revealed large unaddressed risks. Interceptions included 279 insect species, 125 of which were not known to be established in Hawaii, and 47 plantpathogen species, 16 of which were not known to occur in Hawaii (HDOA 2002).

- Current technology to prevent the movement of organisms (e.g., electric and more effective barriers) should be installed in canals that connect major watersheds, especially where at least one watershed harbors a nonindigenous species with a high risk for further invasion. These include the Chicago Ship and Sanitary Canal (which connects the Great Lakes and Mississippi River basins) and canals that connect the Hudson River and Lake Champlain.

- For commercial enterprises that intentionally import live organisms, education is needed to remind consumers that they are often the proximate pathway: individual consumers and travelers are often directly responsible for the release of organisms (Kiritami and Yamamura 2004). An easy-to-understand message should accompany every purchase of a live organism. The general message should be "don't release live organisms," but such a message should be tailored to specific markets, and be accompanied with suggestions for the humane disposal of unwanted organisms. Alternatively, vendors could be required to provide free disposal or re-sale services. One ongoing effort targeting the aquarium trade is the Habitattitude program sponsored jointly by the Pet Industry Joint Advisory Council, the NOAA National Sea Grant College Program, and the U.S. Fish and Wildlife Service (information available online). ${ }^{15}$

- For these same industries, cooperative efforts with scientists and government agencies should increase voluntary efforts to remove invasive species from the market. Scientists working with the horticultural industry and botanical gardens, for example, issued the "Chapel Hill Challenge" to do no harm to plant diversity and natural areas (Reichard and White 2001). In 2002 extended codes of conduct were endorsed by professional organizations of the nursery,

${ }^{15}\langle$ http://www.habitattitude.net/ 
botanical garden, and landscape architect industries, the gardening public, and by relevant government agencies (information available online). ${ }^{16}$ Industry organizations should sponsor programs that fund risk assessments by independent organizations that are authorized to certify that species for sale are not likely to be invasive, and industry partners should accept the results of risk assessments by removing invasive species from collections, and not distributing plants or seeds to locations where the species are likely to become invasive. Similar efforts are needed for the aquaculture and landscape-restoration industries. The degree to which such efforts are effective (reduced releases of organisms) must also be better quantified to assure cost-effective implementation of future efforts.

- Existing scientific evidence provides a sufficient basis for additional government oversight. For example, banning the use of many species used as live bait (Lodge et al. 2000), and restricting the use of many others to local waters where the species can be collected, would lead to rapid prevention of additional aquatic invasions. Species proposed for sale as live bait, especially those species proposed for importation from other continents, must be subject to risk analysis. The management of approved species should include mandatory hazard-reduction practices to prevent the inadvertent introduction of pathogens or other associated species (Gunderson and Kinnunen 2001).

- If outdoor aquaculture continues, containment practices must improve drastically to prevent escapes of nonindigenous species and genotypes (Naylor et al. 2001).

Additional recommendations to reduce risk from the commerce in living organisms are provided in the next section.

\section{Recommendation 2}

Screen live organisms proposed for importation into the United States for environmental, economic, and humanhealth risk before a decision is made to allow entry. Risk analysis tools should be repeatable, transparent, supported by current scientific findings, and applied to all pathways, across all agency jurisdictions.

Current federal approaches to risk assessment of nonindigenous species rely exclusively on qualitative, expert opinion (e.g., protocols used by APHIS and the Aquatic Nuisance Species Task Force). These protocols rarely meet any of the essential criteria for rigorous risk assessments specified by the NRC (2002): peer review, transparency, repeatability, specified uncertainties, and quantitative output. In addition, a very small proportion

16 http://www.centerforplantconservation.org/invasives $\rangle$ of imported species are subject to any screening. There are 14 genera and 10 additional species that are on the U.S. Fish and Wildlife Service's (USFWS) injuriousspecies list (available online), ${ }^{17}$ but most of them were already widespread and the cause of extensive damage before their importation into the United States was made illegal. The federal noxious weed list (available online $)^{18}$ contains more species (96) because of greater attention to protecting agriculture than wildlife. Nevertheless, many of these species too were well established in the United States before their importation was outlawed. Too few USDA or USFWS employees have jobs dedicated to evaluating the risk associated with importations of organisms. Clearly, insufficient resources are devoted to evaluating the risk of species before they are allowed into the country (GAO 2002).

At the federal level, screening protocols must be adopted for all proposed new introductions into the country, so that no species is allowed entry unless the risk of invasiveness, including the invasiveness of any parasites and other hitchhiking organisms, is acceptably low. Screening protocols (but not necessarily their applications to particular species) should be evaluated and peer-reviewed before adoption by agencies. The protocols and every application of them must be transparent (open to review and understandable to those who were not involved) and repeatable (NRC 2002), and uncertainties should be addressed explicitly. Results should be expressed in terms of quantitative probabilities whenever possible.

In the 2001 National Management Plan (NMP), the Department of Agriculture, the Department of the Interior, and the Environmental Protection Agency committed to work jointly toward new risk-assessment screening protocols for invasive species, but there has been little meaningful progress because of the reluctance of different agencies to cooperate. The many published tools that meet the goals and characteristics described above should be added to the federal toolbox to create a flexible approach to risk analysis. We elaborate below on four approaches that we recommend be adopted by federal agencies: environment matching; consideration of propagule pressure (the number of individuals of a species that is released); analysis based on the traits of species; and expert opinion. These tools are complementary, and, where possible, should all be implemented as an overall risk-assessment approach. Some assessments might conclude rapidly, while many proposals for intentional introductions should employ all four of the approaches described below.

\footnotetext{
${ }^{17}$ http//contaminants.fws.gov/OtherDocuments/ InjuriousWildlifeList.htm $\rangle$ PDF $\rangle$
} 


\section{Environmental matching as a predictor of invasion potential}

Assessing the degree to which a new environment is similar to the donor environment is a reasonable starting point for risk analysis. Good computer-based tools are available that provide a first-cut broad geographical answer to the question "Is a species likely to survive in this environment if it were introduced here?" The easily quantifiable physical and chemical axes of a species niche are described and mapped onto other parts of the globe. These tools can be implemented rapidly, and are strong in their analysis of the role of climate and other abiotic factors in limiting distributions of organisms.

Standard methods of environmental matching (also often called "niche modeling") include traditional multivariate statistical methods (e.g., discriminant analysis, multiple regression, logistic regression), often coupled with geographic information systems (GIS) (e.g., Ramcharan et al. 1992, Buchan and Padilla 2000). More recent methods that are tailor-made for identifying potential ranges include CLIMEX (Sutherst et al. 1999), genetic algorithms for rule-set production (GARP) (Peterson and Vieglais 2001, Drake and Bossenbroek 2004), and tools tailored to marine organisms (information available online), ${ }^{19}$ all of which are embodied in user-friendly and readily available software.

Quantifying the degree of similarity between two terrestrial locations is tractable because abundant precipitation and temperature data are available from meteorological stations worldwide, and algorithms can calculate indices of biotic responses to temperature, moisture, and light (Sutherst et al. 1999). This approach is the main quantitative component of the Australian national screening protocol for plants (Australian Quarantine and Inspection Service 2003) and could be extended to the United States (e.g., Venette and Hutchison 1999), but error rates can be high (Pheloung et al. 1999, Kriticos and Randall 2001).

Environmental matching is also possible for aquatic environments (Drake and Bossenbroek 2004, Marchetti et al. 2004a), but currently less tractable than for terrestrial habitats because: (1) fewer aquatic physicochemical data are available in appropriate electronic formats, and fewer distribution data have been collected for aquatic species; (2) terrestrial climatic data are often poor predictors of the aquatic environment; and (3) strongly predictive environmental variables for establishment are unknown for many aquatic species (Carlton et al. 1995).

These environment matching tools also have at least two intrinsic limitations. First, environment matching assumes that no evolution will occur in the nonindige-

\footnotetext{
$19\langle$ www.iobis.org
}

nous species with respect to habitat requirements (Sakai et al. 2001, Cox 2004). Second, biotic interactions in a new environment may limit or facilitate establishment independent of any climatic match (Torchin and Mitchell 2004). The complexities of ecological communities make overcoming these limitations a research challenge, rather than an immediate management application. Thus, environment-matching tools should be augmented with additional risk-assessment approaches.

\section{Propagule pressure as a determinant of the probability of establishment}

The probability of establishment of an introduced species increases as the frequency of release events and the number of individuals released (propagule pressure) increases (Menges 1998, 2000, Kolar and Lodge 2001, Mulvaney 2001). For example, propagule pressures from ships' ballast and hull fouling, and from outdoor aquaculture facilities, are enormous compared with propagule pressure from species that are cultured and kept indoors. Frequency of introductions must also be considered because some pathways, e.g., release of live bait by anglers or the plant seed trade, have low propagule pressure per event but frequent introduction events, so that the new range is subject to an effectively high propagule pressure and therefore a large risk. Finally, the condition (well cared for and healthy is typical of commerce in live organisms compared with transport under marginal conditions for transportationrelated pathways) and life stage (resilient resting stages compared with sensitive juvenile stages) of propagules will also strongly affect the probability of establishment (Smith et al. 1999, Hayes and Hewitt 2000, Wonham et al. 2001). Thus, management actions that reduce the number of released individuals, the number of introduction events, and the health of individuals released are likely to reduce the risk of invasion.

Rigorous quantification of this usually nonlinear relationship is rare. That is, answering the question "How much is risk lowered for a given reduction in propagules?" is more of a research challenge than a management application. Although analyses of population genetics and random fluctuations of births and deaths suggest that only 20 to 500 individuals are needed to maintain an initial population of a sexually reproducing species, many more individuals may be needed to overcome random fluctuations of the environment, natural catastrophes, and the difficulty of finding a mate when population density is very low (Tomiuk and Loeschke 1993, Grevstad 1999, Mack 2000, Drake 2004, Leung et al. 2005). Establishment may occur at lower population levels for vegetatively reproducing organisms because they do not need to find a mate to reproduce. For both sexual and asexual species, however, quantifying the effects of population variability and environmental variability are vitally important to the 
development of specific targets of allowable propagule pressure (Mack 2000).

Despite these complexities and even without detailed quantification of the relationships discussed above, simple indices of propagule pressure offer ready means to improve predictive power and therefore provide management advice for lowering the risk of invasion (Marchetti et al. 2004a). For instance, simple estimates of boat traffic to lakes are predictive of invasions even without knowing the exact propagule pressure, timing or frequency of introductions, or condition of the propagules (Schneider et al. 1998, Bossenbroek et al. 2001). Likewise, at the largest scale, estimates of international trade are positively correlated with invasions (Levine and D'Antonio 2003). Current scientific understanding provides only a general rationale for reducing the propagule pressure, but suggests strongly that consideration of propagule pressure should be a major component of a risk analysis.

\section{Species characteristics as predictors of invasion}

Trait-based screening protocols are available for an increasing number of taxonomic groups and ecosystems, and are increasingly reliable guides to the likelihood of establishment, spread, and impact (e.g., Reichard and Hamilton 1997, Kolar and Lodge 2002, Marchetti et al. $2004 b, c$ ). For all ecosystems studied to date, the most common diagnostic characteristic of a species' potential for invasiveness is a previous invasion history elsewhere in the world, especially for species that have had demonstrable economic or human-health impact (Williamson 1996, Kolar and Lodge 2001, Hayes and Sliwa 2002). But of course this observation is useless for species that have not become established outside their native range, or if surveys in other countries are as incomplete as those in the United States. Fortunately, other traits (e.g., environmental tolerances, life-history characteristics) can be predictive, even for species with no history of invasiveness.

Trait-based analysis has been used for many terrestrial plant invaders (Drake et al. 1989, Perrins et al. 1992, Scott and Panetta 1993, Rejmánek 1996, Rejmánek and Richardson 1996, Reichard and Hamilton 1997, Lee 2001, Reichard and White 2001) and for freshwater fishes (Kolar and Lodge 2002, Marchetti et al. 2004b). While the accuracy of some earlier approaches was not as high as desired (Smith et al. 1999), recent approaches have been highly accurate (e.g., 87-94\% for Kolar and Lodge [2002]), in part because analyses are increasingly controlled for the ecosystem being invaded (Lee 2001), and for each of the multiple steps in the invasion process (Fig. 1). Traits related to success in one of these steps are often not the same traits as those important to other steps; the probability of establishing is related to different traits than the probability of spreading (Kolar and Lodge 2001, 2002, Marchetti et al. 2004c).
The federal government should immediately begin using existing protocols, taking care to apply them for the invasion stage (establishment, spread, or impact), the taxonomic group, and the ecosystem for which each was developed. The federal government should also support the development of additional protocols because the existing number remains small compared to the worldwide number of taxonomic groups and ecosystems. Because these tools are data intensive and require substantial investments for each taxonomic group and ecosystem analyzed, relevant federal agencies should jointly sponsor the development of additional analyses, especially for taxonomic groups likely to be in transport and for ecosystems under high threat of invasion (NRC 2002, Hayes and Sliwa 2002; Fig. 2). The expense of the development of these tools will be more than repaid by the damages avoided by identifying and denying entry to harmful species. The development of these tools is urgent because they enhance transparency, repeatability, and quantification of uncertainty (Burgman 2000, 2001, 2005), characteristics that current federal approaches lack.

\section{Expert opinion encompassed in detailed, qualitative species-specific analyses}

For a species with important ecological or economic issues at stake, a risk analysis might conclude with a comprehensive assessment of all biological data (Burgman 2005). Such analyses have traditionally been conducted by APHIS and the Aquatic Nuisance Species Task Force (e.g., Nico et al. 2001), and have usually required months to years for a committee of experts to conduct, while the three previous steps can be conducted much more rapidly. In addition, these analyses have typically proceeded without transparency or repeatability. New approaches to expert elicitation exist, however, that infuse the use of expert opinion with more transparency, repeatability, and timeliness (Burgmann 2005). Such approaches should be adopted as a final analysis that assesses whether more detailed biological consideration casts any doubt on the statistical evaluations in the previous three steps. These four stepsenvironmental matching, consideration of propagule pressure, trait-based analysis, and expert elicitationwould provide a comprehensive basis for an overall assessment of the magnitude and likelihood of adverse environmental, human health, or economic damage if a nonindigenous species was allowed entry into the country.

\section{Relationship of federal, state, and local risk assessments}

Invasive species do not respect political boundaries. In a country as large and ecologically diverse as the United States, an ecosystem likely exists that would be suitable for growth and reproduction for species from most other parts of the world. Furthermore legal tools and practical 
methods to prevent the transport of a species introduced into one state to another state are rare and many that do exist are rarely used (Kolar 2002) (see also the Environmental Law Institute web site). ${ }^{20}$ Entry requirement into the United States should therefore be stringent and rigorously enforced. Species should be allowed entry only if no U.S. ecosystem exists where the species poses a high risk. For already-established species (including species native to only one part of the United States), the risk-assessment approach described above must be regionalized so that federal, state, and local actions are coordinated to prevent spread into other regions where a species poses an unacceptably high risk.

Such coordination is grossly insufficient now. For example, under the Plant Protection Act of 2000 (U.S. Code Title 7, sections 7701 et seq.), federal "preemption" is sometimes a significant problem for states. If USDA has a federal quarantine program to prevent spread of a pest, it is illegal for a state to impose more stringent restrictions. Federal quarantine has been ineffective in preventing spread of red imported fire ant across the southern continental United States. After the ant reached California, the Hawaii Department of Agriculture tried in 1999 to institute measures to prevent its spread to Hawaii, but two states complained that Hawaii was not legally entitled to require stronger measures than the federal quarantine.

It is therefore essential that the federal governmentespecially the Department of the Interior and the Department of Agriculture-provide strong national leadership. However, under the current weak federal system of species screening, state risk analyses and listings of allowed and prohibited species are critically important. States must use their authority more aggressively to protect their resources even when federal agencies fail to act. Additions to federal listings of noxious weeds or plant pests (under the Plant Protection Act of 2000) or injurious wildlife (under the Lacey Act amendments of 1981 [U.S. Code Title 16, sections 33713378 , and as amended]) will likely continue to be much slower and more contentious than additions to state listings. Moreover, state-specific ecosystems or economic activity that is threatened by invasive species will be more highly valued by the state than by the federal government. Even with more aggressive pathway and species screening and enforcement at the federal and state levels, however, states will remain vulnerable to dispersal of a species permitted in another state. Because invasive species readily cross political boundaries, regional coordination of state policies is essential.

Local governments must also take steps, especially when quick action by a city or county can address an urgent problem. For example, in response to discoveries

$20\langle$ www.eli.org $\rangle$ of live bighead carp for sale in food markets in Chicago, or the emerald ash borer (Agrilus planipennis) found in Michigan, local authorities were quick to respond. Increasing local and state action also increases incentives for industry to support steps at greater geographical scales to avoid a hodge-podge of regulation that might unduly hamper commerce. More effective federalregional-state-local cooperation is clearly required to reduce the number of future invasive species disasters.

Early Detection, Eradication, and Control

\section{Recommendation 3}

Use new technology to improve active surveillance of invasive species to increase the success of rapid response and eradication efforts, in cooperation with existing webbased information networks in universities, herbaria, museums, and state agencies.

Some species will inevitably slip through prevention efforts and establish small populations. A small proportion of these species will spread widely, usually after some lag phase, to become abundant pests (Sakai et al. 2001). The lag time between establishment and spread associated with many invading populations provides an opportunity for detection and eradication. For most species, however, eradication efforts must proceed quickly (within weeks to 1-2 years) if there is to be a substantial probability of success. Thus, detecting populations while they are still small and localized is extremely important. Yet in recent years, only about $2 \%$ of the shipping containers coming into the United States received any inspection whatsoever.

Unfortunately, the effort required to detect a species is inversely proportional to its population size (Barry 2004, Hayes et al. 2005). Hence cost-effective management walks a fine line between the high costs of surveys for small populations, and the high costs of eradication if a survey fails to detect a nascent population in the initial stages of invasion. The technical needs for improved detection for invasive species overlap largely with the needs for surveillance against terrorism (NRC 2003), and cover many of the same locations (e.g., seaports, airports). Thus coordinated efforts to use existing and new technologies against the threat from both terrorism and invasive species should be synergistic for early detection and for prevention (as discussed in the previous section).

\section{Improved sampling, detection, and identification methods}

Monitoring should be concentrated in areas where initial introductions are most likely to occur, including areas surrounding seaports and airports, and other areas where large numbers of shipping containers are received or opened. Areas of high human population or visitation also experience frequent introductions and human disturbance, making establishment more likely (DeFer- 
rari and Naiman 1994, Planty-Tabacchi et al. 1996, Rejmánek 1989, 1999, Stohlgren et al. 1998). Natural areas where an invasion would be especially damaging (e.g., National Forests, National Parks, and other conservation areas) should be intensely monitored, concentrating on sites most likely to have had propagules delivered by humans (e.g., along roadways, paths, streams) (Lonsdale 1999).

Sampling techniques that maximize search area per unit cost, and minimize laboratory costs are likely to return the best cost-benefit ratios (Hayes et al. 2005). Technology already used for other purposes could be easily adapted for use in monitoring nonindigenous species. Examples include the use of gene probes, shotgun sequencing, microarrays, and genetic polymerase chain reaction (PCR)-based tools for quickly detecting small aquatic organisms (Deagle et al. 2003, Tyson et al. 2004, Hayes et al. 2005), and remote sensing for identifying habitats vulnerable to invasion (Chong et al. 2001, Stohlgren et al. 2001, Schnase et al. 2003).

One of the major obstacles to current monitoring and prevention in all ecosystems worldwide is the absence or poor availability of taxonomic keys for identifying species, including different stages in the life cycle. To overcome these problems, training of taxonomists and systematists must increase. This recommendation stands in sharp contrast to the current emphasis in research and training in biology, in which the roles of taxonomy and systematics have declined precipitously in recent decades.

Photographically illustrated taxonomic keys with more comprehensive coverage of life stages and morphologic variation must be readily available, especially on the internet. Cumbersome dichotomous keys should be replaced by on-line "polyclaves" (keys based on multiple, easily recognized characteristics) tailored for parataxonomists, citizen groups, and students. Examples of web-based taxonomic tools exist for aquatic and terrestrial organisms (available online). ${ }^{21}$ Finally, morphological descriptions in computerized keys should be augmented with standard genetic profiles in GenBank (information available online), ${ }^{22}$ or genetic bar codes (Hebert et al. 2003a,b) so that gene probes may be increasingly incorporated into detection protocols $(\mathrm{Ca}-$ hill and Hardham 1994, Patil et al. 2003).

\section{Coordination of governmental, nongovernmental, and volunteer monitoring and data networks}

Amateur naturalists and other citizens have often been the first to discover invasive species. Because members of

${ }^{21}$ URLs for aquatic: /http://www.marine.csiro.au/crimp/ nimpis/ $\rangle$; $\langle$ http://invasions.si.edu/nemesis/index.html $\rangle$; URLs for terrestrial: $\langle$ http://el.erdc.usace.army.mil/pmis/ $\rangle ;\langle\mathrm{http}: / /$ www.ozcam.gov.au/ $/$

${ }^{22}$ /http://www.stn-international.de/stndatabases/databases/ genbank.html $\rangle$ the public that explore the natural world greatly outnumber professional field biologists, establishing methods for the public to bring previously unseen or unknown species to government laboratories, universities, museums, or nature centers should be expanded and widely publicized. Providing standard protocols for citizens to use in monitoring local aquatic and terrestrial habitats can be extremely cost effective, as long as the potentially high cost of false positive reports can be controlled (Wasson et al. 2002, Hegamyer et al. 2003) (see also the North American Weed Management Association web site). ${ }^{23}$

Discoveries of invasive species in new locales by public and private monitoring programs should be made readily available on the internet as quickly as possible. Databases for local monitoring should be linked electronically with other local, regional, national, and international efforts like those listed above (see footnotes 21-22) so that other groups may be forewarned (Ricciardi et al. 2000). This approach is particularly important for rapid response and eradication, where it is imperative to know the existing range and potential distribution of the target species (Schnase et al. 2003). Such taxonomic and network-building efforts should be facilitated and subsidized by the federal government.

\section{Recommendation 4}

Make legal authority and emergency funding available for eradication and control to proceed rapidly once a newly established, potentially invasive species is detected. Current legal mechanisms and funding for responses to agricultural pests and parasites, and to human pathogens, should be extended to all potentially invasive species in all habitats, and employed commensurate with the threat.

Control programs for widespread species are inevitably expensive, such as the $\$ 16$ million annual expenditure to control sea lamprey (Petromyzon marinus) in the Great Lakes. Nevertheless, they are often cost effective; the sea lamprey program, for example, protects a fishery worth about $\$ 4$ billion annually. Control and eradication are, however, most cost effective by following emerging rules of engagement with invasive species: (1) rapid response upon first detection, when populations are still localized (Rejmánek and Pitcairn 2002), (2) placing highest priority on the elimination of species' nascent foci, and (3) thoroughly and repeatedly searching the potential new range for residual organisms to create a virtual zone sanitaire (Mack and Lonsdale 2002). While it may be obvious that small populations are easier to eradicate than large populations, there are added benefits to acting while a population is small. Eliminating the source of seeds or other propagules early may exponentially reduce the long-term costs of

\footnotetext{
${ }^{23}$ 〈www.NAWMA.org
} 
trying to eradicate the species in remote areas to which it would otherwise spread (Myers et al. 2000).

Eradication programs have been successful for many terrestrial plants, mammals, and insects; for some freshwater plants and fishes; and for a few marine algae and invertebrates (Bax et al. 2002, Kuris 2003, Simberloff 2003; see also San Diego [California] Regional Water Control Board, available online). ${ }^{24}$ Many successful terrestrial programs have relied on mechanical removals and chemical applications (Mack and Lonsdale 2002), while aquatic eradications have relied on chemicals. These existing methods should be applied more frequently, but increased effort should also be devoted to developing techniques that are less laborious and that have fewer nontarget effects. Development of methods for eradication in aquatic environments, in particular, requires greater government support. In large freshwater and marine environments, eradication with biocides is often impractical because of dispersal of the biocide and detrimental effects on nontarget species. Although the weaknesses of available methods limit the number of eradication attempts, a greater constraint is the lack of legal authority and emergency funds that can be accessed quickly.

\section{Legal authority}

In the successful eradication of the marine mussel Mytilopsis in Australia, national legislation enabled a rapid response, including quarantine (Bax et al. 2002). In contrast, management of invasive species in the United States is hindered by lack of an overarching federal regulatory authority, and lack of an established mechanism for federal, state, and local coordination. USDA and the Department of Health and Human Services have authority to respond rapidly and aggressively, including quarantine, for agricultural and human pathogens, respectively, but similar authority to protect other economic or environmental goods and services is weak or rarely exerted. For example, local and county ordinances to control noxious weeds on private property and unoccupied land are not routinely enforced. Rapid response to a plant or wildlife parasite or a marine or freshwater invasion in the United States is difficult unless the species is among the few that are already listed as noxious or injurious by USDA or the FWS, respectively. Although a diverse array of federal agencies have some authority to act, overlapping federal, state, and local authorities often stymie rapid action.

Eradication and control programs are routinely slowed or halted by cumbersome permitting procedures that allow damages to increase while management programs are on hold. Longstanding protection of agriculture and forestry from invasive species, including

$$
{ }^{24}\langle\text { http://caulerpa.cjb.net/ }\rangle
$$

invasive plants, parasites, insects, and mammals, has meant that eradication and control protocols are quite effective. In these settings, deliberations to minimize nontarget and other unintended effects have been balanced against the need for expeditious management in the face of damages that grow - often exponentiallyover time. However, the situation for other settings, especially aquatic ecosystems, often hinders effective management.

For marine and freshwater ecosystems, the federal government, in cooperation with states and tribes, should provide parallel procedures for prior approval of control plans for specific species or taxonomic groups that are likely to require control in the future. Many such species - and the habitats they are likely to invade - are readily identified because they are already known in the United States or elsewhere. Such control plans could then be implemented immediately anywhere in the United States with minimal additional review. Specifically, we recommend the following three federal actions to expedite the approval of rapid responses to invasive species:

- Under the National Environmental Protection Act, the federal government should create a provision for a "categorical exclusion" for management of newly discovered potentially invasive species on federal lands, either through rule making or congressional action.

- Congress should make clear that under the Clean Water Act, a National Pollutant Discharge Elimination System (NPDES) permit is not required for the application of approved aquatic herbicides (which are often employed against invasive aquatic or wetland plants).

- Under the Endangered Species Act, the federal government should create a new provision for expedited review of emergency responses to invasive species, either through rule making or congressional action.

Many eradication and control plans that would be approved under these proposed mechanisms would likely consist of integrated management - a combination of mechanical, chemical, and biological control. Treatment combinations are often necessary to compensate for the limitations of each approach, and to minimize the nontarget damage that results from some approaches (Lafferty and Kuris 1996, Anonymous 1999, Wu et al. 1999, Murphy and Goggon 2000, Schardt and Ludlow 2000, Cronk and Fuller 2001, Kilbride and Puveglio 2001, Trowbridge 2001, Kuris 2002).

The changes recommended above must include provisions for broad stakeholder and scientific review of eradication and control plans, and systematic monitoring of management efforts, without unduly delaying either the initiation or progress of the effort. 
Kuris (2003) opined, for example, that control of the European green crab in the United States should have been prioritized over research on its impact, given the crab's rapid spread. However, when initial efforts are not as successful as expected, more costly than anticipated, are projected to have long duration, or entail high nontarget effects, data gathered during the effort may be essential for adjusting future treatments to increase efficacy, lower nontarget effects, and improve cost effectiveness. The urgent need is to provide mechanisms for rapid approval of emergency management plans to ensure that appropriate resources are delivered to any invaded terrestrial or aquatic ecosystem, just as they are now when agriculture or forestry is threatened.

\section{Need for emergency funding}

Greater legal authority and budget provisions for emergency responses must be provided for eradication and control efforts aimed at newly discovered invasive species. Currently, even when agencies recognize a compelling need for rapid response and eradication, their budgets are usually fully committed to core missions. There is a lack of emergency funding sources, perhaps because the damages, while large in aggregate, are usually thinly spread across the public arena. As a result, no sufficiently large incentive arises for any private group to finance a rapid response or to motivate a government response. This situation constitutes a variation of the Tragedy of the Commons. Consequently, the federal government must fund research, development, and implementation of improved strategies for eradication and control. Analogous budgets have long been set aside for responses to wildfires, outbreaks of agricultural and human pathogens, and oil spills. As one option, industries that serve as pathways for invasive species could be required to underwrite the cost of eradication, based on the principle that the primary beneficiaries of a pathway should bear the costs of any resulting damages (Jenkins 2002). Government should provide procedures for internalizing societal costs, which are presently externalities for industries that are pathways for invasive species.

\section{Recommendation 5}

Provide ongoing funding and incentives for slowing the spread of established invasive species on public and private lands, in cooperation with the states and tribal governing bodies.

When eradication is not feasible, a "slow-the-spread" strategy is a rational management choice to augment local control efforts, particularly when the environmental or economic costs of allowing an invader to proceed unmanaged are likely to outstrip management costs. Bearing the cost of new invasions has been the common default strategy in the United States, but is usually not prudent (Leung et al. 2002). For each unit of time during which we prevent an invader from occupying new range, a benefit accrues. For example, based on experience in the U.S. Midwest, we can be fairly certain that if zebra mussels spread into the western states (Drake and Bossenbroek 2004), it will pose a large financial burden on power plants, navigation locks, and other industries that require abundant water. Efforts to stop the westward spread of zebra mussel and other freshwater invasive species (e.g., 100th Meridian Initiative [information available online $)^{25}$ therefore have a high benefit : cost ratio (Leung et al. 2002). Similar examples are common for terrestrial plants and insects such as the emerald ash borer and gypsy moth (Sharov and Liebhold 1998, Sharov et al. 2002; also see the USDA Forest Service web site), ${ }^{26}$ and are increasingly common for marine species in other countries (Ross et al. 2002). For the same reasons that the federal government should provide funding for rapid response, eradication, and control efforts (Recommendation 4, above), the federal government should also fund research and development of slow-the-spread strategies, develop decision tools for prioritizing management efforts (Burgman 2005, Leung et al. 2005), and provide sustained funding and incentives for implementation of these strategies.

\section{Establishing a National Center for Invasive Species Management}

\section{Recommendation 6}

Expand existing authority of the National Invasive Species Council (NISC), including the establishment of a National Center for Invasive Species Management under NISC, to better coordinate policies among government agencies and with other countries.

Current federal policy on invasive species is fragmented and piecemeal, with narrow policy goals distributed among more than 20 federal agencies administering regulations under more than 12 major congressional acts (National Invasive Species Council 2001, Miller and Fabian 2004; see also the National Invasive Species Information Center web site). ${ }^{27}$ Consistent with traditional agency missions, current and proposed federal legislation often addresses one species (e.g., nutria, tamarisk) or taxonomic group (e.g., the genera of terrestrial weeds Striga and Cuscuta), one pathway (e.g., ballast water from shipping), or one stage of invasion (e.g., maintenance control but not prevention). Opportunities for cost effectiveness are lost because the overall process of invasion and the interdependence of management efforts at each invasion stage are not recognized in policy (Fig. 1).

\footnotetext{
25 http://www.100thmeridian.org/ $\rangle$

$26\langle$ http://www.na.fs.fed.us/fhp/eab/ $\rangle$

27 www.invasivespeciesinfo.gov/laws
} 


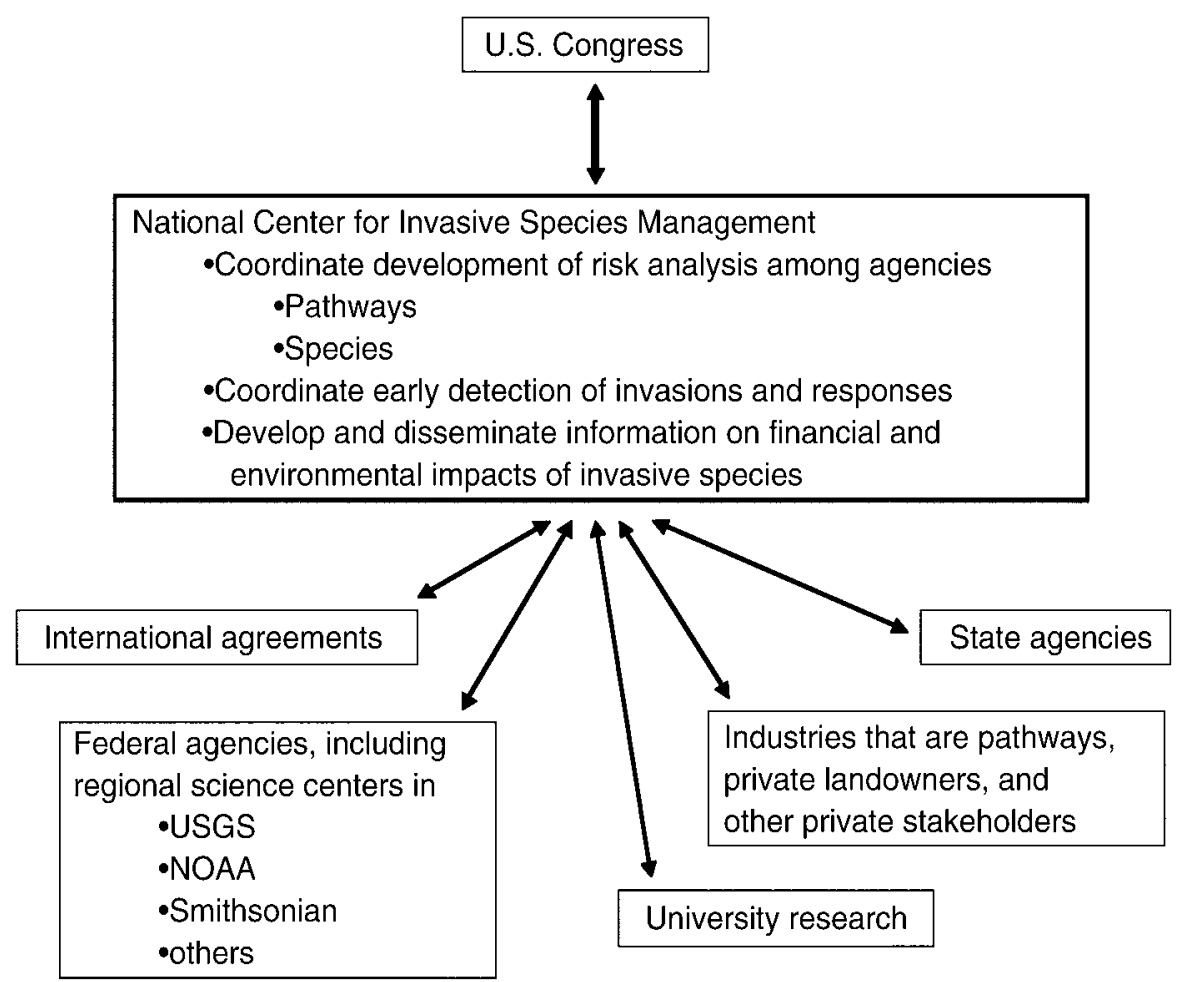

FIG. 3. Schematic of the role of the proposed new National Center for Invasive Species Management (see Recommendation 6). The Center would require dialogue with Congress, consistent with existing reporting links between Executive Branch entities and Congress.

Funds are spent on control of a species, for example, without reducing the supply of new introductions of the same species and of other potentially invasive species. This approach virtually guarantees the necessity of future expenditures to address the same or other species. Coordinating the production and dissemination of information on the importance of different pathways, as well as on the costs of individual invasive species, would prevent such oversights. In addition, such information would increase the speed and cost effectiveness of management and policy by promoting priority setting within and between agencies. Currently, each agency often independently alerts the public to similar threats, and expenditures on some species are duplicative, while some pathways escape management entirely. Invasive-species management is an intrinsically interdisciplinary challenge, and a much more comprehensive approach to policy is essential to protect the country in the most cost-effective manner (Table 1).

Progress toward coordination and a more comprehensive perspective has occurred recently, especially with the creation of the National Invasive Species Council and its working groups and publication of the National Management Plan (National Invasive Species Council 2001). Emergence of a lead government entity with a sufficiently comprehensive focus on invasive species remains hampered however by the multi-jurisdictional intersection of the Departments of Agriculture, Interior, and Commerce, and a lack of authority in NISC. To a considerable degree, the current situation is described as follows: what is all agencies' responsibility is no agency's responsibility. To accomplish the goals described here, Congress should grant authority to the NISC and establish a National Center for Invasive Species Management as a unit of NISC. The Center would require strong, high level executive leadership with substantial scientific and policy expertise.

Policy coordination is not only a critical national issue, but also an urgent international issue. Any species imported by the United States, whether intentionally or as a by-product of trade, puts Canada and Mexico at immediate risk, and any other country with which the United States trades at risk from further international spread. The United States is an exporter as well as an importer of invasive species, and U.S. policies and practices are subject to, or at least relevant to, at least 10 major international agreements (information available online $^{28}$ - even those agreements that the United States has not signed. The development of risk-analysis proto-

\footnotetext{
${ }^{28}\langle$ www.state.gov/e/eb/tpp/c10327.htm $\rangle$
} 
cols (see recommendations 1-3), for example, must proceed in light of emerging guidelines and precedents from the World Trade Organization's Agreement on the Application of Sanitary and Phytosanitary Measures (WTO SPS; Hedley 2004).

The creation of a national Center is an administrative solution to the currently fragmented state of U.S. national and international policy that has federal precedent (Schmitz and Simberloff 2001). Analogous policy shortfalls historically led to successful solutions, such as The Centers for Disease Control and Prevention (CDC [Atlanta, Georgia, USA]), and the National Interagency Fire Center (Boise, Idaho, USA). Both are plausible general models for a new comprehensive national approach to the problem of invasive nonindigenous species. Regardless of which model is followed, several key elements seem essential (Fig. 3). A National Center for Invasive Species Management would:

(1) Coordinate U.S. policy with those of other countries, especially with regard to trade;

(2) Coordinate both the research on risk analysis of pathways by which invasive species are introduced, and implementation of research to prevent additional introductions into the United States. The Center should broker cooperative agreements on risk analysis among existing agencies; currently tools and approaches in combating these species are under development by multiple agencies, take too long to be tested, and much more time to be implemented (see Recommendations 1-2);

(3) Coordinate early detection and rapid-response activities. Nonindigenous species do not reside only within the jurisdictional range of one agency (e.g., national forests, national parks). Rather they readily and increasingly leap across land and bodies of water in public and private ownership, engaging multiple jurisdictions (see Recommendations 3-5). The Center could, for example, maintain a global interagency "watching brief" for new and emerging invasive species, as the CDC does for human diseases; and

(4) Finally, to be effective for the public good, this new Center must report to Congress, as well as to its member agencies, on well-defined operational goals and progress. Congress is reacting to the threat of invasive species with a flurry of new legislation; these bills will only be as effective as the scientific and economic information upon which they are based.

In a way that no current agency can, the Center could enhance information exchange among scientists, public agencies, industries that are pathways, and private stakeholders, and could integrate university and agency-based research into emerging policy and management initiatives (Fig. 3).

\section{Conclusions}

Nonindigenous invasive species pose a severe threat worldwide to the environment, national economies, and human welfare. Greater public and private expenditures would be cost-effective to protect the country from ongoing and future damages. However, losses from invasive species are spread across many stakeholders. As a result, no strong, nationwide private-stakeholder, conservation, or governmental group has emerged to pressure the federal government to more effectively manage this threat. The problem is complex and interdisciplinary (Fig. 1), includes many pathways (Fig. 2), a tremendous diversity of organisms that are invasive, and the vulnerability of all terrestrial, marine, and freshwater ecosystems. Despite this complexity, and the consequent overlapping and sometimes conflicting federal and state policies involved, recent developments provide a strong basis for rapid implementation of costeffective solutions (Table 1). In this report, we have made six recommendations requiring government action in order to help prevent invasions, respond rapidly to new invasions, and control and limit damage from existing invasions. The Ecological Society of America is committed to provide expertise to all levels of government in the application of these recommendations. Although scientific expertise and many private-sector partners are essential for successful responses to invasive species, the federal government must take the lead to implement all six of our recommendations.

\section{ACKNOWLEDGMENTS}

We thank Julie Denslow of the ESA Board of Governors, the ESA Public Affairs Committee, Randall Stocker, anonymous reviewers, and comments from many ESA members for insightful advice on earlier drafts of this manuscript which sharpened its focus and recommendations. Tom Stohlgren and Lloyd Loope provided extensive helpful information and advice. D. M. Lodge thanks Reuben Keller, Sam Lake, Mark Lonsdale, Dennis O'Dowd, and Steve Schoenig for comments, information, and assistance, and the National Science Foundation, the Environmental Protection Agency STAR program, the National Oceanic and Atmospheric Administration Sea Grant, the Fish and Wildlife Service, the Great Lakes Fishery Commission, the U.S. Department of Agriculture Forest Service Ottawa National Forest, and a National Center for Ecological Analysis and Synthesis Sabbatical Fellowship for financial support. Joanna McNulty, Chris Van Loon, and Brett Peters at Notre Dame assisted greatly with the references, figures, and other aspects of manuscript preparation. H. J. MacIsaac is grateful for funding from the Natural Sciences and Engineering Research Council and the Department of Fisheries and Oceans; comments from Marg Dochoda and Doug Jensen are appreciated. For S. Williams, this is contribution number 2351 from the Bodega Marine Laboratory, University of California-Davis.

\section{Literature Cited}

Andow, D. A. 2004. Pathways-based risk assessment of exotic species invasions. Pages 439-455 in G. Ruiz and J. T. Carlton, editors. Invasion pathways. Island Press, New York, New York, USA.

Anonymous. 1999. Report of the Joint SCC/SCFA National Taskforce on the Prevention and Management of Marine Pest Incursions. Department of Agriculture, Fisheries, and Forestry, Canberra, ACT, Australia. 
Australian Quarantine and Inspection Service. 2003. Weed assessment for new plant imports. Department of Agriculture, Fisheries, and Forestry, Canberra, ACT, Australia.

Barry, S. 2004. Sampling designs for pest monitoring programs; design considerations. Bureau of Rural Sciences, Australian Government Department of Agriculture, Fisheries, and Forestry, Canberra, ACT, Australia.

Bax, N., K. Hayes, A. Marshall, D. Parry, and R. Thresher. 2002. Man-made marinas as sheltered islands for alien marine organisms: establishment and eradication of an alien invasive marine species. Pages 26-39 in C. R. Veitch and M. N. Clout, editors. Turning the tide: the eradication of invasive species. IUCN SSC Invasive Species Specialist Group. IUCN [World Conservation Union], Gland, Switzerland, and Cambridge, UK.

Benson, A. J. 1999. Documenting over a century of aquatic introductions in the United States. Pages 1-31 in R. Claudi and J. H. Leach, editors. Nonindigenous freshwater organisms: vectors, biology, and impacts. Lewis Publishers, New York, New York, USA.

Bossenbroek, J. M., J. C. Nekola, and C. E. Kraft. 2001. Prediction of long-distance dispersal using gravity models: zebra mussel invasion of inland lakes. Ecological Applications 11:1778-1788.

Breiman, R. F., M. R. Evans, W. Preiser, J. Maguire, A. Schnur, A. Li, H. Bekedam, and J. S. MacKenzie. 2003. Role of China in the quest to define and control severe acute respiratory syndrome. Emerging Infectious Disease 9:10371041.

Buchan, L. J., and D. K. Padilla. 2000. Predicting the likelihood of Eurasian watermilfoil presence in lakes, a macrophyte monitoring tool. Ecological Applications 10:1442-1445.

Burgman, M. A. 2000. Are Australian standards for risk analysis good enough? Conserving snails and managing genetically modified plants in fragmented landscapes. Australian Biologist 12:125-137.

Burgman, M. A. 2001. Flaws in subjective assessments of ecological risks and means for correcting them. Australian Journal of Environmental Management 8:219-226.

Burgman, M. 2005. Risks and decisions for conservation and environmental management. Cambridge University Press, Cambridge, UK

Cahill, D. M., and A. R. Hardham. 1994. A dipstick immunoassay for the specific detection of Phytophthora cinnamomi in soils. Phytopathology 84:1284-1292.

Campbell, G. L., A. A. Marfin, R. S. Lanciotti, and D. J. Gubler. 2002. West Nile virus. Lancet Infectious Diseases 2: 519-529.

Carlton, J. T., D. M. Reid, and H. van Leeuwen. 1995. Shipping study. The role of shipping in the introduction of non-indigenous aquatic organisms to the coastal waters of the United States (other than the Great Lakes) and an analysis of control options. Part of the National Biological Invasions Shipping Study. United States Coast Guard and the National Sea Grant Program, Washington, D.C., USA.

CDC [Centers for Disease Control]. 2003. Questions and answers about monkey pox. Page 2 in $\langle$ http://www.cdc.gov/ ncidod/monkeypox/index.htm $\rangle$ (4 November 2003).

Chan-Yeung, M., and W. C. Yu. 2003. Outbreak of severe acute respiratory syndrome in Hong Kong special administrative region: case report. British Medical Journal 326:850852.

Chapman, J. W., T. W. Miller, and E. V. Coan. 2003. Live seafood species as recipes for invasion. Conservation Biology 17:1386-1395.

Check, E. 2004. Health concerns prompt U.S. review of exoticpet trade. Nature 427:277.
Chong, G. W., R. M. Reich, M. A. Kalkhan, and T. J. Stohlgren. 2001. New approaches for sampling and modeling native and exotic plant species richness. Western North American Naturalist 61:328-335.

Cohen, A. N., and J. T. Carlton. 1998. Accelerating invasion rate in a highly invaded estuary. Science 279:555-557.

Colautti, R. I., and H. J. MacIsaac. 2004. A neutral terminology to define "invasive" species. Diversity and Distributions 10:135-141.

Colautti, R. I., A. Niimi, C. D. A. van Overdijk, E. L. Mills, K. Holeck, and H. J. MacIsaac. 2003. Spatial and temporal analysis of shipping vectors to the Great Lakes. Pages 227246 in G. M. Ruiz and J. T. Carlton, editors. Bioinvasions: pathways, vectors, and management strategies. Island Press, New York, New York, USA.

Cox, G. W. 2004. Alien species and evolution: the evolutionary ecology of exotic plants, animals, microbes, and interacting native species. Island Press, Washington, D.C., USA.

Cronk, Q. C. B., and J. L. Fuller. 2001. Plant invaders: the threat to natural ecosystems. Earthscan Publications, London, UK.

Davis, M. A., and K. Thompson. 2000. Eight ways to be a colonizer; two ways to be an invader: a proposed nomenclature scheme for invasion ecology. Bulletin of the Ecological Society of America 81:226-230.

Deagle, B. E., N. Bax, C. L. Hewitt, and J. G. Patil. 2003. Development and evaluation of a PCR-based test for detection of Asterias (Echinodermata: Asteroidea) larvae in Australian plankton samples from ballast water. Marine and Freshwater Research 54:709-719.

DeFerrari, C. M., and R. J. Naiman. 1994. A multi-scale assessment of the occurrence of exotic plants on the Olympic Peninsula, Washington. Journal of Vegetation Science 5:247258.

Donlan, C. J., and P. S. Martin. 2004. Role of ecological history in invasive species management and conservation. Conservation Biology 18:267-269.

Drake, J. A., H. A. Mooney, P. di Castri, R. H. Groves, P. J. Kruger, M. Rejmánek, and M. Williamson, editors. 1989. Biological invasions: a global perspective. John Wiley and Sons, New York, New York, USA.

Drake, J. M. 2004. Allee effects and the risk of biological invasion. Risk Analysis 24:795-802.

Drake, J. M., and J. M. Bossenbroek. 2004. The potential distribution of zebra mussels in the United States. BioScience 54:931-941.

Drake, J. M., and R. P. Keller. 2004. Environmental justice alert: do developing nations bear the burden of risk for invasive species? BioScience 54:718-719.

Drake, J. M., and D. M. Lodge. 2004. Effects of environmental variation on extinction and establishment. Ecology Letters 7: 26-30.

Fuller, P. L., L. G. Nico, and J. D. Williams. 1999. Nonindigenous fishes introduced into inland waters of the United States. American Fisheries Society, Bethesda, Maryland, USA.

Galatowitsch, S. M., N. O. Anderson, and P. D. Ascher. 1999. Invasiveness in wetland plants in temperate North America. Wetlands 19:733-755.

GAO [U. S. Government Accounting Office]. 2002. Invasive species: clearer focus and greater commitment needed to effectively manage the problem. GAO-03-1. U.S. Government Printing Office, Washington, D.C., USA.

Grace, J. B., M. Smith, S. L. Grace, S. Collins, and T. J. Stohlgren. 2001. Interactions between fire and invasive plants in temperate grasslands in North America. Pages 40-65 in K. Galley and T. Wilson, editors. Fire Conference 2000: the first national congress on fire, ecology, prevention and manage- 
ment. Invasive species workshop: the role of fire in the control and spread of invasive species. Tall Timbers Research Station, Tallahassee, Florida, USA.

Grevstad, F. S. 1999. Experimental invasions using biological control introductions: the influence of release size on the chance of population establishment. Biological Invasions 1: 313-323.

Gunderson, J. L., and R. E. Kinnunen. 2001. Aquatic nuisance species - hazard analysis and critical control point training curriculum. Minnesota Sea Grant, Duluth, Minnesota, USA.

Hayes, K. R., R. Canaon, K. Neil, and G. Inglis. 2005. Sensitivity and cost considerations for the detection and eradication of marine pests in ports. Marine Pollution Bulletin. 50:823-834.

Hayes, K. R., P. C. Gregg, V. V. S. R. Gupta, R. Jessop, M. Lonsdale, B. Sindel, J. Stanley, and C. K. Williams. 2004. Identifying hazards in complex ecological systems. Part 3. Hierarchical holographic model for herbicide tolerant oilseed rape. Environmental BioSafety Research 3:1-20.

Hayes, K. R., and C. L. Hewitt. 2000. Risk assessment framework for ballast water introductions. Volume II. CRIMP Technical Report 21. Centre for Research on Introduced Marine Pests, CSIRO Marine Research, Hobart, Tasmania, Australia.

Hayes, K. R., and C. Sliwa. 2002. Identifying potential marine pests - a deductive approach applied to Australia. Marine Pollution Bulletin 46:91-98.

HDOA [Hawaii Department of Agriculture]. 2002. Kahului Airport risk assessment. Hawaii Department of Agriculture, Plant Quarantine Division, Honolulu, Hawaii, USA.

Hebert, P. D. N., A. Cywinska, S. L. Ball, and J. R. deWaard. 2003a. Biological identifications through DNA barcodes. Proceedings of the Royal Society of London B: Biological Sciences 270:313-321.

Hebert, P. D. N., S. Ratnasingham, and J. R. deWaard. $2003 b$. Barcoding animal life: cytochrome $\mathrm{c}$ oxidase subunit 1 divergences among closely related species. Proceedings of the Royal Society of London B: Biological Sciences 270:596599.

Hedley, J. 2004. The international plant protection convention and invasives. Pages 185-202 in M. L. Miller and R. N Fabian, editors. Harmful invasive species: legal responses. Environmental Law Institute, Washington, D.C., USA.

Hegamyer, K., S. P. Nash, and P. D. Smallwood. 2003. The early detectives: how to use volunteers against invasive species. Case studies of volunteer early detection programs in the U.S. The University of Richmond, Environmental Studies Program, Richmond, Virginia, USA.

Jenkins, P. T. 2002. Paying for protection from invasive species. Issues in Science and Technology 19:67-72.

Jeschke, J. M., and D. L. Strayer. 2005. Invasion success of vertebrates in Europe and North America. Proceedings of the National Academy of Sciences (USA) 102:7198-7202.

Kilbride, K. M., and F. L. Paveglio. 2001. Long-term fate of glyphosate associated with repeated Rodeo applications to control smooth cordgrass (Spartina alterniflora) in Willapa Bay, Washington. Archives of Environmental Contamination and Toxicology 40:179-183.

Kiritani, K., and K. Yamamura. 2003. Exotic insects and their pathways for invasion. Pages 44-67 in G. M. Ruiz and J. T. Carlton, editors. Bioinvasions: pathways, vectors, and management strategies. Island Press, New York, New York, USA.

Kolar, C. S., and D. M. Lodge. 2001. Progress in invasion biology: predicting invaders. Trends in Ecology and Evolution 16:199-204.

Kolar, C. S., and D. M. Lodge. 2002. Ecological predictions and risk assessment for alien fishes in North America. Science 298: $1233-1236$.
Kraus, F. 2003. Invasion pathways for terrestrial vertebrates. Pages 68-92 in G. M. Ruiz and J. T. Carlton, editors. Bioinvasions: pathways, vectors, and management strategies. Island Press, New York, New York, USA.

Kriticos, D. J., and R. P. Randall. 2001. A comparison of systems to analyse potential weed distributions. Pages 61-79 in R. H. Groves, F. D. Panetta, and J. G. Virtue, editors. Weed risk assessment. CSIRO Publishing, Collingwood, Victoria, Australia.

Kuris, A. 2002. Biological control of the European green crab, Carcinus maenas: a progress report. Pages 66-70 in M. S. Hoddle, editor. Proceedings of the Third California Conference on Biological Control, 15-16 August 2002, University of California-Davis. CABI Publishing, Wallingford, Oxfordshire, UK.

Kuris, A. 2003. Eradication of introduced marine pests. Pages 543-550 in D. J. Rapport, B. L. Lasley, D. E. Rolston, N. O. Nielsen, C. O. Qualset, and A. B. Damania, editors. Managing for healthy ecosystems. Lewis Publishers, New York, New York, USA.

Lafferty, K. D., and A. M. Kuris. 1996. Biological control of marine pests. Ecology 77:1989-2000.

Lee, M. 2001. Non-native plant invasions in Rocky Mountain National Park: linking species traits and habitat characteristics. Colorado State University, Fort Collins, Colorado, USA.

Les, D. H., and L. J. Mehrhoff. 1999. Introduction of nonindigenous aquatic vascular plants in southern New England: a historical perspective. Greater New England Symposium on the Ecology of Invasive Species. Yale School of Forestry and Environmental Studies, New Haven, Connecticut, USA.

Leung, B., D. Finnoff, J. F. Shogren, and D. M. Lodge. 2005. Managing invasive species: rules of thumb for rapid assessment. Ecological Economics 5:24-36.

Leung, B., D. M. Lodge, D. Finnoff, J. F. Shogren, M. A. Lewis, and G. Lamberti. 2002. An ounce of prevention or a pound of cure: bioeconomic risk analysis of invasive species. Proceedings of the Royal Society of London Series B: Biological Sciences 269:2407-2413.

Levine, J. M., and C. M. D'Antonio. 2003. Forecasting biological invasions with increasing international trade. Conservation Biology 17:322-326.

Lingappa, J. R., L. C. McDonald, P. Simone, and U. D. Parashar. 2004. Commentary. Wrestling SARS from uncertainty. Emerging Infectious Diseases 10:167-170.

Linthicum, K. J., V. L. Kramer, M. B. Madon, and K. Fujioka. 2003. Introduction and potential establishment of Aedes albopictus in California in 2001. Journal of the American Mosquito Control Association 19:301-308.

Lodge, D. M., and K. Shrader-Frechette. 2003. Nonindigenous species: ecological explanation, environmental ethics, and public policy. Conservation Biology 17:31-37.

Lodge, D. M., C. A. Taylor, D. M. Holdich, and J. Skurdal. 2000. Nonindigenous crayfishes threaten North American freshwater biodiversity: lessons from Europe. Fisheries 25:720 .

Lonsdale, W. M. 1999. Global patterns of plant invasions and the concept of invasibility. Ecology 80:1522-1536.

Mack, R. N. 2000. Cultivation fosters plant naturalization by reducing environmental stochasticity. Biological Invasions 2: 111-122.

Mack, R. N. 2003. Global plant dispersal, naturalization and invasion: pathways, modes and circumstances. Pages 3-30 in G. M. Ruiz and J. T. Carlton, editors. Bioinvasions: pathways, vectors, and management strategies. Island Press, New York, New York, USA. 
Mack, R. N., and W. M. Lonsdale. 2002. Eradicating invasive plants: hard-won lessons for islands. Pages 164-172 in D. Veitch and M. Clout, editors. Turning the tide: the eradication of invasive species. Invasive Species Specialty Group of the World Conservation Union (IUCN), Auckland, New Zealand.

Mack, R. N., D. Simberloff, W. M. Lonsdale, H. Evans, M. Clout, and F. A. Bazzaz. 2000. Biotic invasions: causes, epidemiology, global consequences, and control. Ecological Applications 10:689-710.

Malecki, R. A., B. Blossey, S. D. Hight, D. Schroeder, L. T. Kok, and J. R. Coulson. 1993. Biological-control of purple loosestrife. BioScience 43:680-686.

Marchetti, M. P., T. Light, P. B. Moyle, and J. H. Viers. 2004a. Fish invasions in California watersheds: testing hypotheses using landscape patterns. Ecological Applications 14:15071525.

Marchetti, M. P., P. B. Moyle, and R. Levine. 2004b. Alien fishes in California watersheds: characteristics of successful and failed invaders. Ecological Applications 14:587-596.

Marchetti, M. P., P. B. Moyle, and R. Levine. 2004c. Invasive species profiling: exploring characteristics of non-native fishes across invasion stages in California. Freshwater Biology 49: 646-661.

Menges, E. S. 1998. Evaluating extinction risks in plant populations. Pages 49-65 in P. L. Fielder and P. M. Karieva, editors. Conservation Biology. Chapman and Hall, New York, New York, USA.

Menges, E. S. 2000. Population viability analyses in plants: challenges and opportunities. Trends in Ecology and Evolution 15:51-56.

Miller, M. L., and R. N. Fabian. 2004. Harmful invasive species: legal responses. Environmental Law Institute, Washington, D.C., USA.

Mooney, H. A., R. N. Mack, J. A. McNeely, L. E. Neville, P. J. Schei, and J. K. Waage, editors. 2005. Invasive alien species: a new synthesis. Island Press, Washington, D.C., USA.

Moore, C. G. 1999. Aedes albopictus in the United States: current status and prospects for further spread. Journal of the American Mosquito Control Association 15:221-227.

Mulvaney, M. 2001. The effect of introduction pressure on the naturalization of ornamental woody plants in south-eastern Australia. Pages 186-193 in R. H. Groves, F. D. Panetta, and J. G. Virtue, editors. Weed risk assessment. CSIRO Publishing, Collingwood, Victoria, Australia.

Murphy, N. E., and C. L. Goggon. 2000. Genetic discrimination of sacculinid parasites (Cirripedia, Rhizocephala): implications for control of introduced green crabs (Carcinus maenas). Journal of Crustacean Biology 20:153-157.

Myers, J. H., D. Simberloff, A. M. Kuris, and J. R. Carey. 2000. Eradication revisited: dealing with exotic species. Trends in Ecology and Evolution 15:316-320.

National Invasive Species Council. 2001. Meeting the invasive species challenge: national invasive species management plan. National Invasive Species Council, Washington, D.C., USA.

Naylor, R., S. L. Williams, and D. R. Strong. 2001. Aquaculture - a gateway for exotic species. Science 294: $1655-1656$.

Nico, L. G., J. D. Williams, and J. J. Herod. 2001. Black carp (Mylopharyngodon piceus): a biological synopsis and updated risk assessment. Risk Assessment and Management Committee, USGS, Gainesville, Florida, USA.

NRC [National Research Council]. 1996. Understanding risk: Informing decisions in a democratic society. National Academies Press, Washington, D.C., USA.

NRC [National Research Council]. 2002. Predicting invasions by nonindigenous plants and plant pests. National Academies Press, Washington, D.C., USA.
NRC [National Research Council]. 2003. Non-native oysters in the Chesapeake Bay. National Academies Press, Washington, D.C., USA.

O'Dowd, D. J., P. T. Green, and P. S. Lake. 2003. Invasional "meltdown" on an oceanic island. Ecology Letters 6:812-817.

Padilla, D. K., and S. L. Williams. 2004. Beyond ballast water: aquarium and ornamental trades as sources of invasive species in aquatic ecosystems. Frontiers in Ecology and the Environment 2:131-138.

Palm, M. E., and A. Y. Rossman. 2003. Invasion pathways of terrestrial plant-inhabiting fungi. Pages $31-43$ in G. M. Ruiz and J. T. Carlton, editors. Bioinvasions: pathways, vectors, and management strategies. Island Press, New York, New York, USA.

Patil, J., K. R. Hayes, R. Gunasekera, B. E. Deagle, F. McEnnulty, N. Bax, and C. L. Hewitt. 2003. Port of Hastings national demonstration project-verification of the type II error rate of the ballast water decision support system. CSIRO Marine Research, Hobart, Tasmania, Australia.

Perrins, J., M. Williamson, and A. Fitter. 1992. A survey of differing views of weed classification-implications for regulation of introductions. Biological Conservation 60:4756.

Peterson, A. T., and D. A. Vieglais. 2001. Predicting species invasions using ecological niche modeling: new approaches from bioinformatics attack a pressing problem. BioScience 51:363-371.

Pheloung, P. C., P. A. Williams, and S. R. Halloy. 1999. A weed risk assessment model for use as a biosecurity tool for evaluating plant introductions. Journal of Environmental Management 57:239-251.

Pimentel, D., R. Zuniga, and D. Morrison. 2005. Update on the environmental and economic costs associated with alieninvasive species in the United States. Ecological Economics 52:273-288.

Planty-Tabacchi, A. M., E. Tabacchi, R. J. Naiman, C. DeFerrari, and H. Decamps. 1996. Invasibility of speciesrich communities in riparian zones. Conservation Biology 10: 598-607.

Pysek, P., D. M. Richardson, M. Rejmanek, G. L. Webster, M. Williamson, and J. Kirschner. 2004. Alien plants in checklists and floras: towards better communication between taxonomists and ecologists. Taxon 53:131-143.

Rahel, F. J. 2002. Homogenization of freshwater faunas. Annual Review of Ecology and Systematics 33:291-315.

Ramcharan, C. W., D. K. Padilla, and S. I. Dodson. 1992. Models to predict potential occurrence and density of the zebra mussel, Dreissena polymorpha. Canadian Journal of Fisheries and Aquatic Sciences 49:2611-2620.

Randall, J. M., and J. Marinelli. 1996. Invasive plants: weeds of the global garden. Brooklyn Botanic Garden, Brooklyn, New York, USA.

Reichard, S. H., and C. W. Hamilton. 1997. Predicting invasions of woody plants introduced into North America. Conservation Biology 11:193-203.

Reichard, S. H., and P. White. 2001. Horticulture as a pathway of invasive plant introductions in the United States. BioScience 51:103-113.

Reiter, P., and D. Sprenger. 1987. The used tire trade: a mechanism for the worldwide dispersal of container-breeding mosquitoes. Journal of American Mosquito Control Association 3:94-501.

Rejmánek, M. 1989. Invasibility of plant communities. Pages 369-388 in J. A. Drake, H. A. Mooney, and F. DiCastri, editors. Biological invasions: a global perspective. John Wiley, New York, New York, USA. 
Rejmánek, M. 1996. A theory of seed plant invasiveness: the first sketch. Biological Conservation 78:171-181.

Rejmánek, M. 1999. Invasive plant species and invasible ecosystems. Pages 79-102 in O. T. Sandlund, P. J. Schei, and A. Vilken, editors. Invasive species and biodiversity management. Kluwer, Dordrecht, The Netherlands.

Rejmánek, M., and M. J. Pitcairn. 2002. When is eradication of exotic plants a realistic goal? Pages 249-253 in C. R. Veitch and M. N. Clout, editors. Turning the tide: the eradication of invasive species. IUCN SSC Invasive Species Specialist Group, IUCN [World Conservation Union], Gland Switzerland, and Cambridge, UK.

Rejmánek, M., and D. M. Richardson. 1996. What attributes make some plant species more invasive? Ecology 77:16551661.

Ricciardi, A., W. W. M. Steiner, R. N. Mack, and D. Simberloff. 2000. Towards a global information system for invasive species. BioScience 50:239-244.

Richardson, D. M., P. Pysek, M. Rejmanek, M. G. Barbour, F. D. Panetta, and C. J. West. 2000. Naturalization and invasion of alien plants: concepts and definitions. Diversity and Distributions 6:93-107.

Rixon, C. A. M., I. C. Duggan, N. M. N. Bergeron, A. Ricciardi, and H. J. MacIsaac. 2005. Invasion risks posed by the aquarium trade and live fish markets on the Laurentian Great Lakes. Biodiversity and Conservation 14:1365-1381.

Ross, D. J., C. R. Johnson, and C. L. Hewitt. 2002. Impact of introduced seastars Asterias amurensis on survivorship of juvenile commercial bivalves Fulvia tenuicistata. Marine Ecology Progress Series 241:99-112.

Ruiz, G., and J. Carlton. 2004. Invasion pathways. Island Press, New York, New York, USA.

Sakai, A. K., et al. 2001. The population biology of invasive species. Annual Review of Ecology and Systematics 32:305332.

Sala, O. E., et al. 2000. Biodiversity-global biodiversity scenarios for the year 2100. Science 287:1770-1774.

Schardt, J., and J. Ludlow. 2000. Status of the aquatic plant maintenance program in Florida public waters. Aquatics 22 . 9-13.

Schmitz, D. C., J. D. Schardt, A. J. Leslie, F. A. Dray, Jr., J. A. Osborne, and B. V. Nelson. 1993. The ecological impact and management history of three invasive alien plant species in Florida. Pages 173-194 in B. N. McKnight, editor. Biological pollution: the control and impact of invasive exotic species. Indiana Academy of Science, Indianapolis, Indiana, USA.

Schmitz, D. C., and D. Simberloff. 2001. Needed: a national center for biological invasions. Issues in Science and Technology 17:57-62.

Schnase, J. L., J. Cushing, M. Frame, A. Frondorf, E. Landis, D. Maier, and A. Silberschatz. 2003. Information technology challenges of biodiversity and ecosystems informatics. Information Systems 28:339-345.

Schneider, D. W., C. D. Ellis, and K. S. Cummings. 1998. A transportation model assessment of the risk to native mussel communities from zebra mussel spread. Conservation Biology 12:788-800.

Scott, J. K., and F. D. Panetta. 1993. Predicting the Australian weed status of Southern African plants. Journal of Biogeography 20:87-93.

Sharov, A. A., D. Leonard, A. M. Liebhold, E. A. Roberts, and W. Dickerson. 2002. "Slow the Spread": a national program to contain the gypsy moth. Journal of Forestry 100:30-35.
Sharov, A. A., and A. M. Liebhold. 1998. Model of slowing the spread of gypsy moth (Lepidoptera: Lymantriidae) with a barrier zone. Ecological Applications 8:1170-1179.

Simberloff, D. 2003. Eradication-preventing invasions at the outset. Weed Science 51:247- 253.

Smith, L. D., M. J. Wonham, L. D. McCann, G. M. Ruiz, A. H. Hines, and J. T. Carlton. 1999. Invasion pressure to a ballast-flooded estuary and an assessment of inoculant survival. Biological Invasions 1:67-87.

Stohlgren, T. J., M. Lee, K. A. Bull, Y. Otsuki, and C. A. Villa. 1998. Riparian zones as havens for exotic plant species in the central grasslands. Plant Ecology 138:113-125.

Stohlgren, T. J., Y. Otsuki, C. Villa, M. Lee, and J. Belnap. 2001. Patterns of plant invasions: a case example in native species hotspots and rare habitats. Biological Invasions 3:37-50.

Stokstad, E. 2003. Invasive species. Can well-timed jolts keep out unwanted exotic fish? Science 301:157.

Sutherst, R. W., G. F. Maywald, T. Yonow, and P. M. Stevens. 1999. CLIMEX user guide - predicting the effects of climate on plants and animals. CSIRO Publishing, Collingwood, Victoria, Australia.

Tomiuk, J., and V. Loeschcke. 1993. Conditions for the establishment and persistence of transgenic organisms. Pages 117-133 in F. Wohrmann and J. Tomiuk, editors. Transgenic organisms: risk assessment of deliberate release. Birkhauser Verlag, Basel, Switzerland.

Torchin, M. E., and C. E. Mitchell. 2004. Parasites, pathogens, and invasions by plants and animals. Frontiers in Ecology and the Environment 2:183-190.

Trowbridge, C. D. 2001. Host-plant change in marine specialist herbivores: ascoglossan sea slugs on introduced macroalgae. Ecological Monographs 71:219-243.

Tyson, G. W., J. Chapman, P. Hugenholtz, E. E. Allen, R. J. Ram, P. M. Richardson, V. V. Solovyev, E. M. Rubin, D. S. Rokhsar, and J. F. Banfield. 2004. Community structure and metabolism through reconstruction of microbial genomes from the environment. Nature 428:37-43.

Van Auken, O. W. 2000. Shrub invasions of North American semiarid grasslands. Annual Review of Ecology and Systematics 31:197-215.

Venette, R. C., and W. D. Hutchison. 1999. Assessing the risk of establishment by pink bollworm (Lepidoptera : Gelechiidae) in the southeastern United States. Environmental Entomology 28:445-455.

Vitousek, P. M., C. M. D'Antonio, L. L. Loope, and R. Westbrooks. 1996. Biological invasions as global environmental change. American Scientist 84:468-478.

Wasson, K., K. Lohrer, M. Crawford, and S. Rumrill. 2002. Non-native species in our nation's estuaries: a framework for an invasion monitoring program. National Estuarine Research Reserve Technical Report Series 2002:1.

Williamson, M. 1996. Biological invasions. Chapman and Hall, London, UK.

Wonham, M. J., W. C. Walton, G. M. Ruiz, A. M. Frese, and B. S. Galil. 2001. Going to the source: role of the invasion pathway in determining potential invaders. Marine Ecology Progress Series 215:1-12.

Wu, M. Y., S. Hacker, D. Ayers, and D. R. Strong. 1999. Potential of Prokelisia spp. as biological control agents of English cordgrass, Spartina anglica. Biological Control 16: 267-273.

Zohrabian, A., M. I. Meltzer, R. Ratard, K. Billah, N. A. Molinari, K. Roy, R. D. Scott, II, and L. R. Petersen. 2004. West Nile virus economic impact, Louisiana, 2002. Emerging Infectious Diseases 10:1736-1744. 